\title{
Economic Crises and the Eligibility for the Lender of Last Resort: Evidence from 19th century France
}

\author{
Vincent Bignon ${ }^{1}$, Clemens Jobst ${ }^{2}$ \\ Working Paper \#618
}

January 2017

\section{ABSTRACT}

This paper shows that a central bank can more efficiently mitigate economic crises when it broadens eligibility for its discount facility to any safe asset or solvent agent. We use difference-in-differences panel regressions and emulate crises by studying how defaults of banks and non-agricultural firms were affected by the arrival of an agricultural disease. We exploit the specificities of the implementation of the discount window to deal with the endogeneity of the access to the central bank to the arrival of the crisis and local default rates. We find that broad eligibility reduced significantly the increase in the default rate when the shock hit the local economy. A counterfactual exercise shows that defaults would have been $10 \%$ to $15 \%$ higher if the Bank of France would have implemented the strictest eligibility rule. This effect is identified independently of changes in policy interest rates and the fiscal deficit.

Keywords: E32, E44, E51, E58, N14, N54.

JEL classification: discount window, collateral, Bagehot rule, central bank, default rate.

\footnotetext{
${ }^{1}$ Banque de France

${ }^{2}$ Oesterreichische Nationalbank

Working Papers reflect the opinions of the authors and do not necessarily express the views of the Banque de France. This document is available on the Banque de France Website. 


\section{NON-TECHNICAL SUMMARY ${ }^{3}$}

Who should have access to central bank refinancing and which assets should be eligible for central bank operations? Among central banks today, answers to these questions vary widely. Some central banks give almost every financial institution direct access to their refinancing operations and against a widely defined set of collateral including e.g. corporate bonds or credit claims. Other central banks restrict their normal operations to a small set of counterparties allowing them to use only the most liquid investment-grade assets like treasury bills or government bonds. In normal times these differences matter little. When a crisis hits a financial system, however, eligibility suddenly moves center stage.

During those times, having access to the central bank and disposing of the required collateralcan decide about the survival of many. As a result, central banks often adjust their eligibility framework in response to crises, as evidenced by the many new lending programs created by some central banks to fight the panic in the fall of 2008. At the same time, central banks have been criticized for being too accommodative at the risk of bailing-out institutions at the expense of the general public.

The eligibility regime and changes therein are difficult to evaluate empirically because the counterfactual is difficult to come by. What would be needed is two groups of identical banks, one being eligible for central bank refinancing while the other is not. In reality,however, eligibility is always tied to some economic criteria so that non-eligible counterparties (and assets) differ per definition from eligible counterparty in a number of important economic dimensions, rendering a proper comparison between the two groups impossible.

We argue that a wine crisis in 19th century France provides a unique natural experiment to circumvent the constraints normally faced when testing the effects of eligibility on economic outcomes. We exploit a peculiarity of 19th century central bank operations where eligibilitywas tied to geographical criteria. As a result depending on their location otherwise identical firms had better or worse access to central bank refinancing. The second element in our empirical strategy is the crisis triggered by a negative productivity shock brought about by an agricultural disease, phylloxera that dramatically affected French winegrowers. Using this particular crisis has a number of advantages. First, the arrival of phylloxera is clearly exogenous to having a local access or not to the central bank. We can thus exclude that easier access had fueled risk taking behavior and hence triggered the crisis. Second, because the phylloxera affected some districts more than others and spread gradually onto the French territory, we better control for other confounding factors. Finally, we can exclude a potential counter-cyclical impact of fiscal policy by working with a historical case in which the government did not intervene.

\footnotetext{
${ }^{3}$ We thank participants at workshops of the Norges Bank, Chicago Fed, Bundesbank and Banco de España, as well as of the meetings of the Economic History Association, Royal Economic Society and of seminars at the European Central Bank (CFI seminar), Banque de France, the universities of Paris Nanterre, Orléans, Strasbourg, LSE and Sao Paulo. We are grateful to Olivier Accominotti, Pamfili Antipa, Olivier Armantier, Jean Barthélémy, Régis Breton, Eve Caroli, James Costain, Martin Eichenbaum, Marc Flandreau, Christian Hellwig, Phil Hoffman, Alejandra Irigoin, Antoine Martin, Kris Mitchener, Christian Pfister, Jean-Charles Rochet, Philippe de Rougemont, Isabel Schnabel, Pierre Sicsic, Jean Tirole, Stefano Ugolini, François Velde, Eugene White and Bernhard Winkler for comments and discussions. We thank Claudine Coulaud and Charlotte Coutand for data collection.
} 
Our analysis uses a hand-collected uniquely rich administrative dataset documenting the number of defaults and the stock of non-agricultural firms in each of the 85 French districts as well as local information on eligibility and other explanatory variables. The estimations show that the better access to central bank lending provided by local branch offices of the Bank of France significantly lowered defaults by non-agricultural firms. A counterfactual exercise shows that defaults would have been $10 \%$ to $15 \%$ higher if the Bank of France would have implemented the strictest eligibility rule, an economically significant magnitude. Importantly, the decline in defaults did not require the central bank to purchase loss-making assets, surely the outcome of a tight risk management framework. We can thus exclude that the Bank of France bailed out the private sector by taking over worthless assets.

The results of our estimations are thus consistent with the view that broad eligibility helps mitigate the adverse effects of economic crises. If there is a lesson to draw from this past experience in terms of today's monetary policy, our results stress the importance of the operational framework used by the central bank to implement its monetary policy. 


\section{RÉSUMÉ : CRISES ÉCONOMIQUES ET PRÊT EN DERNIER RESSORT : LES LEÇONS DE LA FRANCE DU XIX ${ }^{\text {ÈME }}$ SIÈCLE}

Une banque centrale peut plus efficacement atténuer la sévérité des crises économiques en opérant sa fenêtre d'escompte avec une règle d'éligibilité élargi à tout actif sûr ou à tout agent économique solvable. Ce principe stratégie empirique pour montrer ce principe emploie des régressions en panels. Nous étudions comment la crise du phylloxera, qui décima les vignes entre 1862 et 1890, augmenta les défauts des entreprises non agricoles dans les départements, et utilisons les spécificités du système de refinancement des effets de commerce pour traiter les problèmes d'endogénéité de l'éligibilité aux crises. Nous montrons que les départements dotés de davantage de succursales ont connu une augmentation plus faible de leur taux de défaut quand la crise les a touchés. Un exercice contrefactuel montre que l'effet économique est significatif : Le taux de défaut agrégé aurait été augmenté de 10 à 15\% si la Banque de France avait opéré la fenêtre d'escompte sur la règle d'éligibilité la plus restrictive. Ce résultat est entièrement dû à la politique d'éligibilité à la banque centrale, et n'est pas expliqué par une politique budgétaire contra-cyclique ou par des ajustements du taux directeur de la banque centrale.

Mots-clés : Escompte, collatéral, Règle de Bagehot, banque centrale, taux de défaut. 


\section{Introduction}

Who should have access to central bank refinancing and which assets should be eligible for central bank operations? The optimal design of central bank intervention aimed at mitigating economic crises is a subject of age-old controversy since Thornton (1802) and Bagehot (1873). Among central banks today, answers to these questions vary widely. Some central banks give almost every financial institution direct access to their refinancing operations and against a widely defined set of collateral including e.g. corporate bonds or credit claims. Other central banks restrict their normal operations to a small set of counterparties allowing them to use only the most liquid investment-grade assets like treasury bills or government bonds, but feature eligibility extensions during crisis (BIS, 2013; BIS-CGFS, 2015). In normal times these differences matter little. When a crisis hits a financial system, however, eligibility suddenly moves center stage. During those times, having access to the central bank and disposing of the required collateral can decide about the survival of many. At the same time, central banks have been criticized for being too accommodative at the risk of bailing-out institutions at the expense of the general public.

This paper analyses whether the design of a lender of last resort facility has a real impact on the economy. It studies the benefit of granting broad and direct access to the lender of last resort (LLR), compared to a counterfactual situation in which the central bank intervenes through a small number of eligible counterparties or allows only a restricted subset of financial assets as collateral in its lending. Results show that the central bank stabilizes income shocks in terms of defaults of firms if it lends freely against the widest range of collateral and to the broadest number of (solvent) economic agents.

Three factors impede the quantitative assessment of eligibility frameworks. First, crises are rare events. Second, most variations in eligibility are endogenous to crises, which when anticipated may trigger moral hazard and fuel concern on reverse causality. Third, most variations in eligibility are simultaneous to other policy changes, which bring concern on confounding factors. Our empirical design allows us to overcome all three impediments.

In order to be able to isolate the effect of eligibility on the economic outcome the empirical test requires the following ingredients: An aggregate negative shock must hit several economies and increase the demand for money (lending of last resort). Yet the shock must not be explained by agents taking more risks in expectation of having access to the lender of last resort facility (thus excluding that our results are driven by moral hazard). In addition, the shock must hit several economies that differ with respect to the degree of eligibility to the central bank but otherwise are all subject to identical monetary and fiscal 
policies. We claim that a quasi natural experiment in 19th century France combines these ingredients. The setting allows us to build a difference-in-differences strategy and to show that the central bank softened the impact of the crisis when it allowed the broadest possible access to its lending of last resort facility.

Starting in 1863 the local economies of France were hit by a series of negative productivity and capital shocks that hit different French districts (départements of a size equivalent to an average U.S. county) at different points in time. The shock was brought about by an agricultural disease caused by the insect phylloxera. Phylloxera killed nearly all vines in an economy in which wine production was both important and widespread (Banerjee et al., 2010). Wine production decreased significantly. Neither the fiscal authority nor the central bank attempted to attenuate the effects of the collapse of wine production (Bignon et al., 2016). The agricultural productivity shock translated into an aggregate shock on local banking systems as well as services and industry (Postel-Vinay, 1989). To identify the effects of eligibility to central bank operations we exploit a peculiarity of 19th century central bank operations where eligibility was tied to geographical criteria and thus differed across districts. As the arrival and spreading of phylloxera was a clearly exogenous event we can exclude that the crisis was triggered by moral hazard behavior linked to expectations of eligibility extensions. Econometric identification is helped by the fact that the shock brought by phylloxera affected some districts more than others and did not arrive everywhere at the same time thus allowing to better control for other confounding factors. Finally, we exclude a potential counter-cyclical impact of fiscal policy by working with a case in which the government did not intervene.

Our analysis uses a uniquely rich administrative hand-collected dataset documenting the number of defaults and the stock of non-agricultural firms in each of the 85 districts as recorded by the ministry of justice and the finance ministry. We also have information on the inclusiveness of the eligibility rule at the district level. Our panel includes yearly data spanning over the 1826 to 1913 period. At the high point of the pandemia, which ravaged France from 1863 to $1890,71.3 \%$ of districts were infected.

We run two types of panel regressions. First, we show that the crises of local economies triggered by phylloxera significantly increased defaults of non-agricultural firms. Second, we regress the default rate of non-agricultural local firms on the depth of the local economic crisis, a measure of the inclusiveness of the eligibility for the central bank and an interaction term. Results show that districts with broader eligibility for the central bank experienced a less marked increase in the default rate of banks and firms in services and industry than did districts with stricter eligibility rules. The results are robust across var- 
ious specifications and to the correction for spatial autocorrelation in the error terms. We exclude that eligibility was endogenous by showing that variations in eligibility at the district level were uncorrelated with the spread of the disease, measures of the economic crisis triggered by phylloxera or variations in the district default rate. Finally, we show that the central bank did not make losses on its extended discount operations. The-ceteris paribusobserved decrease in the default rate was thus due to central bank eligibility only and not to a quasi-fiscal subsidy by the central bank.

Our results relate to two strands in banking and monetary theory. The theory supporting lending of last resort emphasizes its beneficial impact either when the payment system is threatened by a crisis (Flannery, 1996) or in the case of a run on financial intermediaries (Freixas et al., 2004). Subsequent research studying the optimal design of the access to the lender of last resort has emphasized the trade-off between the benefits in terms of stabilization and the costs in terms of moral hazard (Chapman and Martin, 2013; Bindseil and Jablecki, 2013) or if there is a stigma associated to the use of central bank facilities (Armantier et al., 2015). Our paper focuses on the role of lending of last resort in protecting the payment system and is consistent with the view that lending of last resort helps alleviating crises when the central bank can screen the quality of its counterparties.

Our paper also echoes the papers in monetary theory that study whether changes in the composition of the asset side of the central bank balance sheet affect real allocations. Changes in the asset side of the central bank balance sheet matter when financial markets are segmented (Gertler and Kiyotaki, 2010; Cúrdia and Woodford, 2011) or when money is more liquid than the debts purchased by the central bank (Chamley and Polemarchakis, 1984; Kiyotaki and Moore, 2005; Venkateswaran and Wright, 2014). ${ }^{1}$ We show empirically that the composition of the central bank balance sheet and the design of the operational framework can positively affect the economic outcome.

The remainder of the paper is organized as follows. Section 2 presents our empirical strategy. Section 3 discusses the identification assumptions on eligibility and on crises that are rooted in the historical analysis of 19th century France. Section 4 presents the data. Section 5 describes the dynamic spread of the shock. Section 6 discusses the statistical and economic significance of the results, and the robustness checks. Section 7 concludes.

\footnotetext{
${ }^{1}$ Wallace (1981) established the irrelevance result stating that exchanging one debt (money) against another (e.g. government debt) leaves unchanged the real allocation. Chamley and Polemarchakis (1984) show that the irrelevance result hinges upon the assumption in Wallace (1981) that money does not provide transaction services. Recent research has clarified that the irrelevance result is overturned if the central bank can screen the assets with the same level of expertise than other financial market participants, see for example Williamson (2014).
} 


\section{Empirical strategy}

Our goal is to determine whether variations in the proportion of assets eligible for the central bank discount window had an impact on the variation in the default rate of banks, services and industry at the district level when the economy was hit by the phylloxera crisis. We estimate this relation using a difference-in-differences approach. Our main equation is the following:

$$
D R_{i t}=\begin{array}{r}
\beta \cdot \text { Shock }_{i t}+\eta \cdot \text { Elig }_{i t}^{\text {BoF }}+\gamma \cdot \text { Shock }_{i t} \cdot \text { Elig }_{i t}^{\text {BoF }}+\theta \cdot \text { Elig }_{i t}^{\text {FIs }} \\
+\xi \cdot \text { Shock }_{i t} \cdot \text { Elig }_{i t}^{F I s}+\kappa \cdot \text { Controls }_{i t}+\delta_{t}+\alpha_{i}+\nu_{i} \cdot t+\epsilon_{i t}
\end{array}
$$

where $D R_{i t}$ stands for the default rate in district $i$ during year $t$ of banks and firms operating in services or industry. The explanatory variables are $S h o c k_{i t}$, which measures whether the district was hit by an exogenous shock that generated an economic crisis in district $i$ during year $t, E l i g_{i t}^{B o F}$, which measures the exposure of district $i$ to the treatment during year $t$ and the interacted term $S_{h o c k} * E_{i t}$ Iig $_{i t}^{B o F}$, which is the product of the variable $S_{h o c k}$ with variable $E l i g_{i t}^{B o F}$. Because private financial intermediaries can also lend to the private sector and hence mitigate the impact of the shock, we include the same variable but measured for private deposit banks. We label it Elig $g_{i t}^{F I s}$, see section 3.3 for details on the measurement of eligibility in 19th century France. A vector of controls Controls $s_{i t}$ is added to account for other determinants of the default rate in district $i$ during the year $t$; see section 4.2 for details. All residuals are clustered at the district level.

We are interested in knowing whether the $\gamma$ coefficient in front of the interacted term $S_{\text {Shock }} *$ Elig $_{i t}^{B o F}$ is significant and negative. Our identification assumption is that absent any friction, the eligibility framework of the central bank should not have any impact on the default rate of firms since everybody can trade his holdings of non-eligible assets against assets eligible at the discount window at no cost. Conversely, if there are some costs, we expect $\gamma$ to be negative and significant, since some agents holding non-eligible assets are unable to exchange them against money, and hence may have to default. Because the Bank of France was not the only potential provider of liquidity, we include national deposit banks as alternative source of funding through which the impact of the shock on the default rate could have been limited and test whether the coefficient $\gamma$ is significant even after taking the refinancing activities of other financial intermediaries into account. Therefore $\gamma$ is pinning down the specific effect of lending of last resort services of the central bank.

The spatial structure of the data might raise concerns about the correlation of the error terms between districts, which in turn might bias the estimated coefficients or change the standard errors. In particular, there might be determinants of the dependent variable that 
were omitted from the model but that are spatially autocorrelated, meaning that the error term is correlated between nearby districts. To show the robustness of our result to the correction for potential spatial autocorrelation, we estimate the following model:

$$
\begin{array}{r}
\beta \cdot \text { Shock }_{i t}+\eta \cdot \text { Elig }_{i t}^{\text {BoF }}+\gamma \cdot \text { Shock }_{i t} \cdot \text { Elig }_{i t}^{\text {BoF }}+\theta \cdot \text { Elig }_{i t}^{F I s}+ \\
\xi \cdot \text { Shock }_{i t} \cdot \text { Elig }_{i t}^{F I s}+\kappa \cdot \text { Controls }_{i t}+\delta_{t}+\alpha_{i}+\nu_{i} \cdot t+\lambda W \cdot \nu_{t}+\epsilon_{i t}
\end{array}
$$

Equation 2 is identical to equation (1) with the difference that the error term $v_{i t}$ allows for spatial correlation between error terms. $W$ denotes a spatial weights matrix based on the distance between the capital cities of the districts, where we assume a declining impact of errors from districts that are further away. $\lambda$ measures the extent of spatial correlation, where zero means that there is no spatial correlation and a higher $\lambda$ means stronger spatial spill-overs.

Finally we check the endogeneity of the Eligit variable to either the default rate $D R_{i t}$ or the shock variable $S h o c k_{i t}$ by estimating a Cox duration model explained in details in section 6.3 .

\section{Historical background}

In this section we first describe the two types of debt instruments that could be used to smooth income shocks in 19th century France (section 3.1). We then discuss the refinancing facilities offered by the Bank of France (section 3.2) before we show how a peculiarity of the 19th century French financial system can be exploited to construct a measure of eligibility to central bank operations that varies at the district level (section 3.3). Finally, we explain why the phylloxera-induced crisis is a good quasi-natural experiment to exclude that the local economic crisis it triggered was caused by moral hazard or the expectation of a central bank bail-out (section 3.4).

\subsection{The financial system and the smoothing of crises in 19th century France}

In 19th century France, agents could resort to two types of debt instruments when they needed to weather a negative income shock: short- and long-term debt. Long-term debt was not intermediated by banks but by notaries (Hoffman et al., 2001). Notaries acted as matchmakers between agents with excess savings and others in need of funds. Each notary operated on a local market (usually a town) and used his private proprietary information on

contractual relationships between families to screen the wealth of savers and indebtedness of borrowers. Based on this information notaries were able to assortatively match lenders and 
borrowers depending on the characteristics of the loans like e.g. their duration, see Hoffman et al. (2015). Segmentation across notaries was pretty strong. Notaries had no interest in sharing information with colleagues (Postel-Vinay, 1997, chapter 1), which prevented the pooling of borrowers and lenders across notaries' clienteles and limited the notaries' capacity to smooth income shocks, in particular when shocks were regionally concentrated.

The other main class of debt was the bill of exchange. A bill of exchange was an instrument for short-term credit, typically for a term of a couple of months up to a year (Roulleau, 1914). In French law, a bill was an order to pay some amount of money - gold or silver coins and banknotes - to the bearer at some pre-determined future date in some specified location (Dalloz, 1830). Bills were negotiable before maturity and could be sold at face value, a deduction being made for the interest rate, the so-called discount. As a result bills were used both as instrument of credit as well as instrument of payment.

The negotiability of bills was aided by the specific legal provision of joint liability. In the process of negotiating - i.e. discounting - of a bill, the previous owner endorsed the bill thereby guaranteeing the following purchaser of the bill to pay in case of a default of the ultimate debtor. If a bill was discounted several times, each endorser became jointly liable together with the other endorsers of the end-payment of the bill (Santarosa, 2015). Hence, everybody figuring on a bill had some "skin in the game". If the debtor defaulted by not paying at maturity, the French jurisprudence endowed the creditor (the holder of the bill) with the right to immediately activate the guarantees once the creditor had proven the inability of the debtor to pay, using a simple procedure called protest ("protêt faute de paiement"), see Tate (1868). With the protest in his hand the creditor was allowed to immediately ask for payment at the home of every endorser as well as the creditor who had initially drawn the bill (Bravard-Veyrières and Demangeat, 1862). ${ }^{2}$ The guarantee had to be activated within a couple of days at the latest.

Strategic default on debt obligations was harshly punished and hence incredibly very costly (Dalloz, 1830; Percerou, 1935). As long as the creditors had not been entirely reimbursed, debtors were not allowed to restart and manage any business. In a failure procedure,

\footnotetext{
${ }^{2}$ According to French law there were three relevant parties to a bill: The tireur drew a bill on the tiré (debtor) against whom he had a previous claim. To obtain cash before the due date the tireur passed on (discounted) the bill with an escompteur, typically a bank, who now became the creditor. The escompteur could either hold the bill in his portfolio and demand payment from the tiré when the bill fell due or rediscount the bill with another bank or the Bank of France, which now became the new creditor. In order to be eligible for rediscount at the Bank of France the bill had to carry three signatures, typically the signatures of the tireur, the tiré, who by his signature (acceptation) acknowledged the validity of the claim, and the escompteur. In case of non-payment by the tiré, these signatures allowed the Bank of France (or any other creditor holding the bill at maturity) to take recourse against the other two parties.
} 
if creditors agreed on debt restructuring and allowed the continuation of the debtor's business (under a "concordat"), the defaulter did not recover his commercial and civil rights before the full reimbursement of all debts. The cost of default and the possibility to immediately activate guarantees in case of non-payment made bills of exchange a safe and liquid instrument.

The business of discounting bills was not regulated and was open to everybody (Kaufmann, 1914; Plessis, 1991). But the four main types of participants in the discount market were the national and regional deposit banks, local unit banks but also shadow banks known as discounters, which were often local merchants or wealthy individuals who employed excess funds in discounting.

While the rules governing the default on bills of exchange made bills a safe and liquid investment they created at the same time a mechanism that could amplify the consequences of a default and might lead to a sudden drying-up of liquidity in the bills market. This could happen in particular when as a consequence of a negative income shocks traders started to anticipate a cascade of defaults. As bills did not benefit from an opt-out clause in the failure procedure, creditors had to wait until the end of the procedure to recuperate the proceeds of their debt (Percerou, 1935). Even though creditors on average recovered a significant percentage of their claim when the procedure ended, a normal length of the procedure between one and two years meant that any exogenous increase in default increased the percentage of illiquid debts in the economy and hence the likelihood of being unable to repay the debt in due time. Anecdotal evidence abounds that when payment incidents started, it was difficult to prevent them because of the stay of creditors in a lengthy procedure and the impossibility to exit it before its legal termination (Cameron, 1967). ${ }^{3}$ As bills of exchange also served as a means of payment, a cascade of defaults threatened the usual working of the payment system. Gille (1959) provides evidence that in times of financial stress local market discount rates skyrocketed in the small towns where no discount facility was operated by the Bank of France. Those rates, that measured the price of converting a short-term credit instrument into coins or banknotes occasionally attained levels as high as $18 \%$ to $30 \%$ (Gille, 1959, p. 145-8).

\subsection{The Bank of France as lender of last resort}

The central bank -the Bank of France- was a publicly listed company endowed with the monopoly of banknotes issuance in the French cities in which it operated a branch (Leclercq,

\footnotetext{
${ }^{3}$ Honoré de Balzac' novel César Biroteau exemplified this issue.
} 
2010). Its goal, defined in its charter, was to refinance bankers and any other type of trader on demand. To this end the Bank purchased bills of exchange outright. ${ }^{4}$ In line with its statutory goals and given that banking was not regulated, any firm specialized in either banking, services or industry could submit bills for discounting at the Bank of France. The only sector excluded was farming, until rules were amended in 1898, well after the end of the Phylloxera crisis, (Ramon, 1929; Baubeau, 2004).

The Bank of France did not buy bills on a market with open-market operations. Rather, discounting was organized as a standing facility where the Bank of France stood ready to purchase bills on demand in its offices from agents in need of cash. The Bank's incorporation law restricted the Bank to buy bills maturing within the three months that followed their purchase. The purchase price was determined by the bill face value deduction made for the discount rate times the residual maturity. By law, the discount rate was uniform across France and could not be adjusted to local conditions or the specific risk profile of the counterparties, which means that the bank could only deny eligibility to lower-quality bills rather than demanding a risk premium. ${ }^{5}$

The Bank of France policy during crises was to accommodate any increase in the demand for refinancing from sound traders (Juglar, 1889; Bouvier, 1979). Starting in the 1850s the Bank implemented Bagehot's rule of free lending against collateral considered to be of good quality in normal times (Bignon et al., 2012). The volume of discounting of the Bank was not restricted by the adherence to the conversion of banknotes in gold or silver, because of its sizable gold and silver reserve in comparison with the value of circulating banknotes (Flandreau, 1996a,b; Contamin and Denise, 1999). ${ }^{6}$ There was therefore no aggregate constraint on the volume of refinancing, which was decided together with the discount rate by the governing body of the Bank in Paris in which private shareholders had a two-third majority over the representatives of the government (Plessis, 1985). The bank paid dividends every semester to its private shareholders and was formally independent of the government (Leclercq, 2010).

\footnotetext{
${ }^{4}$ Banknotes could also be obtained through collateralized lending, called advances ( "avances sur titres"), where agents pledged some publicly traded securities such as railway or government securities. For the sake of simplicity, the discussion here focuses on discounting but the argument can be easily extended to the collateralized lending facility as well.

${ }^{5}$ See the 1808 decree on the statute of the bank.

${ }^{6}$ As argued in Eichengreen and Flandreau (1997, p. 5) "the larger circulation of both gold and silver insulated [it] from disturbances in the availability of the two metals".
} 


\subsection{Geographical constraints on the eligibility of assets to the lender of last resort}

The law required the owner of the bill to collect the payment at the debtor's door. The possibility to buy and hold bills to maturity was constrained by the size of this area since payment collectors have to physically go to the debtor's place. ${ }^{7}$ It followed that only bills payable in a city in which the Bank of France operated a branch office ( "succursale") were possibly eligible for its discount window. Another consequence was that the share of local traders eligible for the discount window varied across districts because of the technological constraint created by the specificities of the payment of bills at maturity.

As this technology did not change significantly over the whole 19th century, the extension of assets eligible for discounting was directly tied to the setting-up of new local collection facilities. Between 1815 and 1836 the only office operated by the Bank of France was in Paris, which de facto restricted discounting to bills payable in Paris. Figure 1 presents the evolution of the number of branches operated by the Bank of France between 1826 and 1913. The gradual extension of the branch network not only allowed more agents to become eligible as a counterparty of the bank but it also made more bills eligible, thereby extending the share of assets - among all assets - against which central bank money could be obtained. At the same time, certain districts had to wait long to receive a branch office and many towns never received any, as the fixed cost of setting up and operating branches prevented banks from opening them everywhere, see also infra in section 6.3. In 1913 the number of branches in each district varied between 1 (mostly agricultural districts) and 9 (in the highly industrial district "Nord").

The uneven distribution of branch offices on the French territory - it was only in 1877 that the Bank of France was present in every French district - creates variations in eligibility over both space and time. Section 6.3 discusses the policy of branch opening by the Bank of France and shows that the Bank did not vary its eligibility policy in response to the economic crises we study or to the level of the default rate. Branching is exogenous. As a result, we can use the geographic restriction on central bank access to compare the impact of economic crises across regions as a function of the eligibility for discounting at the Bank of France.

The only other type of financial institution that had the organization and technology to smooth regionally concentrated illiquidity-driven defaults by redistributing liquidity across districts were the few deposit banks that operated on a national level, most notably the

\footnotetext{
${ }^{7}$ Note that unlike other financial intermediaries who could sell on (rediscount) bills, the central bank was obliged to hold bills to maturity and thus to organize the collection of payment at maturity.
} 


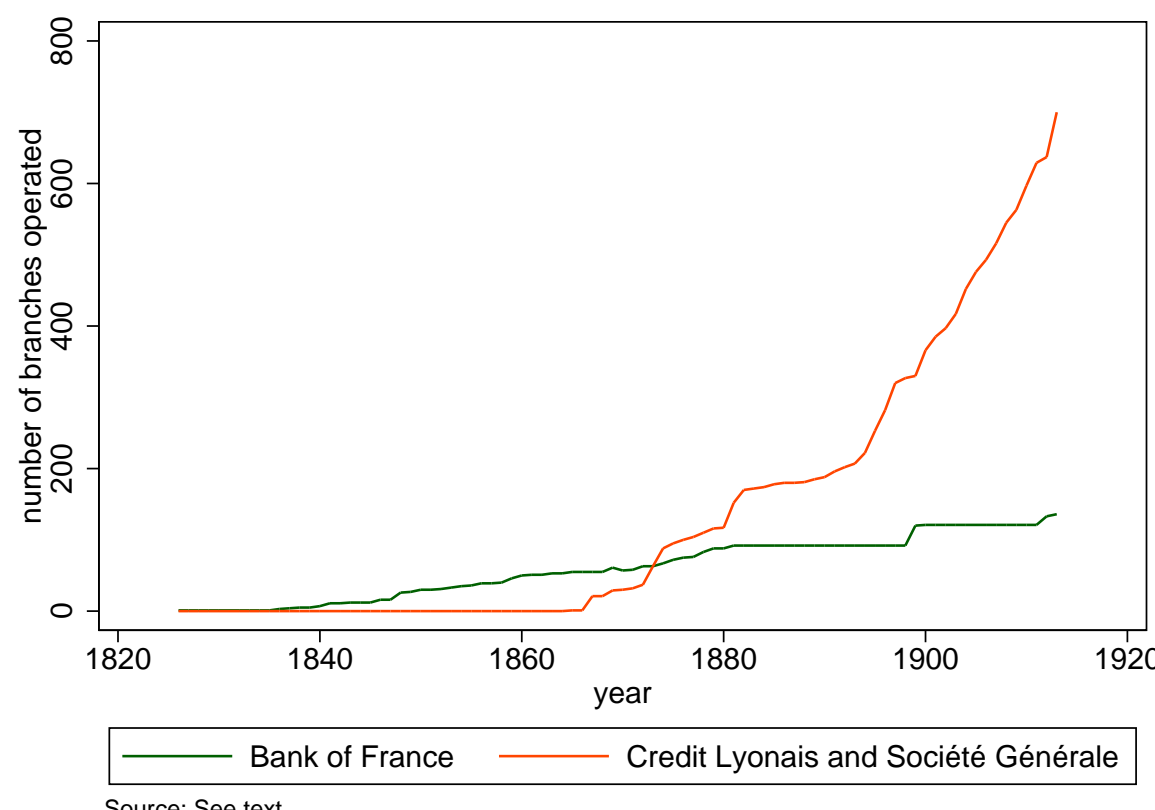

Figure 1: Number of branches operated by the Bank of France and the two main national deposit banks, 1850-1913

Crédit Lyonnais and Société Générale. These national deposit banks were technically capable to increase discounting in branches located in districts affected by a crisis using the deposits of agents living in unaffected districts, very much like the Bank of France could resort to its right to issue banknotes. ${ }^{8}$ An important difference between deposit banks and the central bank was, however, that the opportunity cost of resources must have been much smaller in the case of the central bank. Most deposit banks operated an internal capital market on which branches located in districts with high liquidity demand could borrow the funds necessary to discount bills (Billoret, 1969). Starting in the 1860s, deposit banks developed extensive networks of branches (see figure 1), with the aim of collecting deposits and discounting local bills of exchange, entering thereby into fierce competition with the Bank of France to attract prime bills at their discount windows, see Bouvier (1973) and Lescure (2003). In the regressions we control for the presence of national deposit banks.

\footnotetext{
${ }^{8}$ Both types of banks used the same technology to screen and monitor the discounting of short-term bills, although the central bank discounted on harsher terms, usually at a higher rate and with higher credit standards (Bouvier, 1973).
} 


\subsection{Economic crises: Phylloxera, the bug that shocked local economies}

The second ingredient in our quasi experimental setting is the negative productivity shock brought about by the arrival of an agricultural disease in economies in which agriculture was the most important source of income. Once the disease arrived in a district, it started destroying the vineyards, reducing local wine production and making wine growers poorer (Banerjee et al., 2010; Bignon et al., 2016). As a result, defaults in services and industry increased.

The disease was caused by the near microscopic aphid phylloxera vastatrix - literally the killer of the vineyard - which sinks its pointed snout into the roots of the vine and sucks out the sap. Its saliva infects the roots at the attacked points preventing the wound from healing. This way phylloxera not only causes yields to fall to zero, but kills the plants themselves within a short time. The approximate time between the arrival of the pest and the death of the plant was about a year (Pouget, 1990).

Phylloxera started infecting French vineyards in 1863 (Gale, 2011, p. 18) and then spread gradually onto the French territory. The effects of the aphid were first noticed in 1863 near the Rhone river in the South of France, and soon thereafter in the Bordeaux region. Figure 2 and 3 show the geographic spread of the disease between 1871 and 1877 . Yet the speed of destruction was not uniform across time and space. For example between 1871 and 1879 the south-east district of Gard lost $83 \%$ of its vineyards while neighboring Hérault lost "only" 59\% (Lachiver, 1988, p. 416).

It took a long time to understand why the vines were dying and even longer to understand what could be done about it. The insect was first hypothesized as an explanation to the dying vines in 1868, after the study of a dead vineyard near the Rhône by the botany professor Jules E. Planchon. After that identification, a debate raged for seven years before the scientific community agreed that the appearance of the bug was in fact the cause and not just a consequence of the disease. Academics tried various treatments to fight the pest but none proved helpful for winegrowers (Pouget, 1990). It is only in 1890 that a cure was found and popularized. The solution involved grafting European vines onto phylloxera resistant American stock.

The arrival of phylloxera caused a brutal drop of wine growers' revenues. In a mostly agricultural country, the share of wine production amounted to $6.4 \%$ of the pre-aphid 1862 GDP. In 1870, wine represented a source of income for $21 \%$ of the population (Millardet, 1877 , p. 82). At the same time, the impact of phylloxera varied a lot across districts, as some of them did not grow any vines, while wine production could reach up to $54 \%$ 


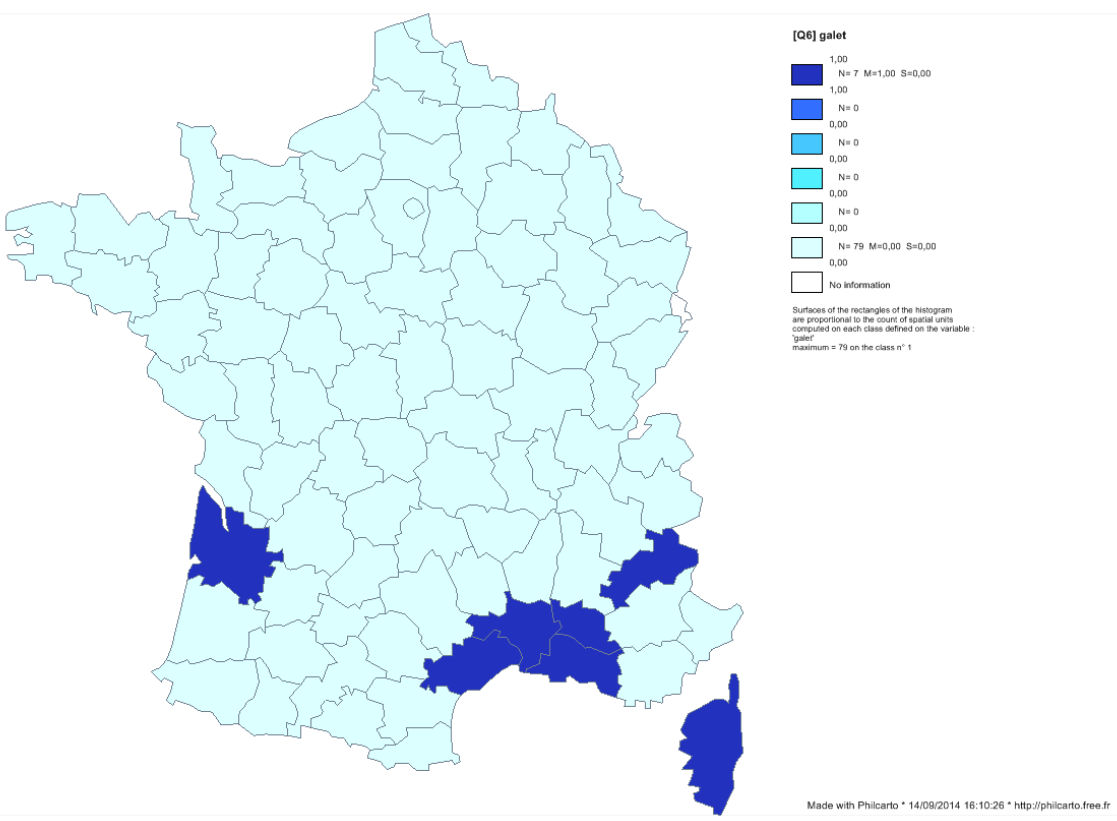

Figure 2: Districts infected by the phylloxera in 1871

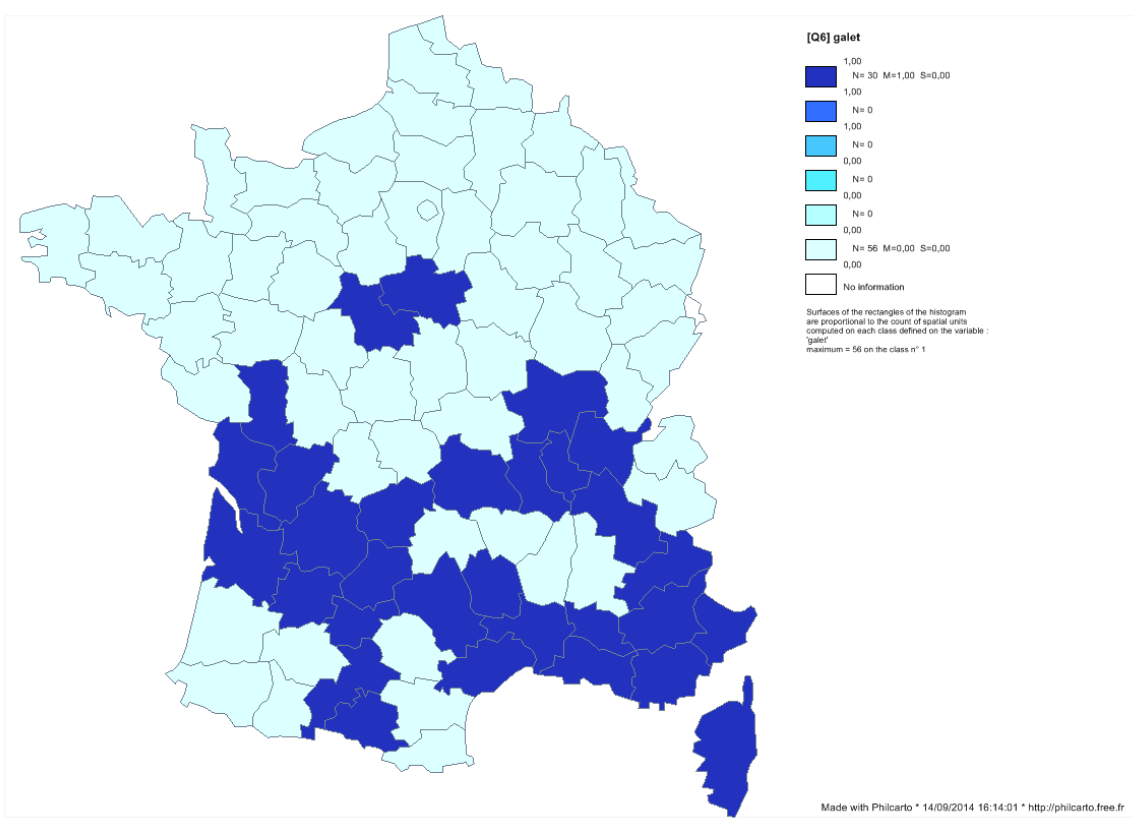

Figure 3: Districts infected by the phylloxera in 1877 


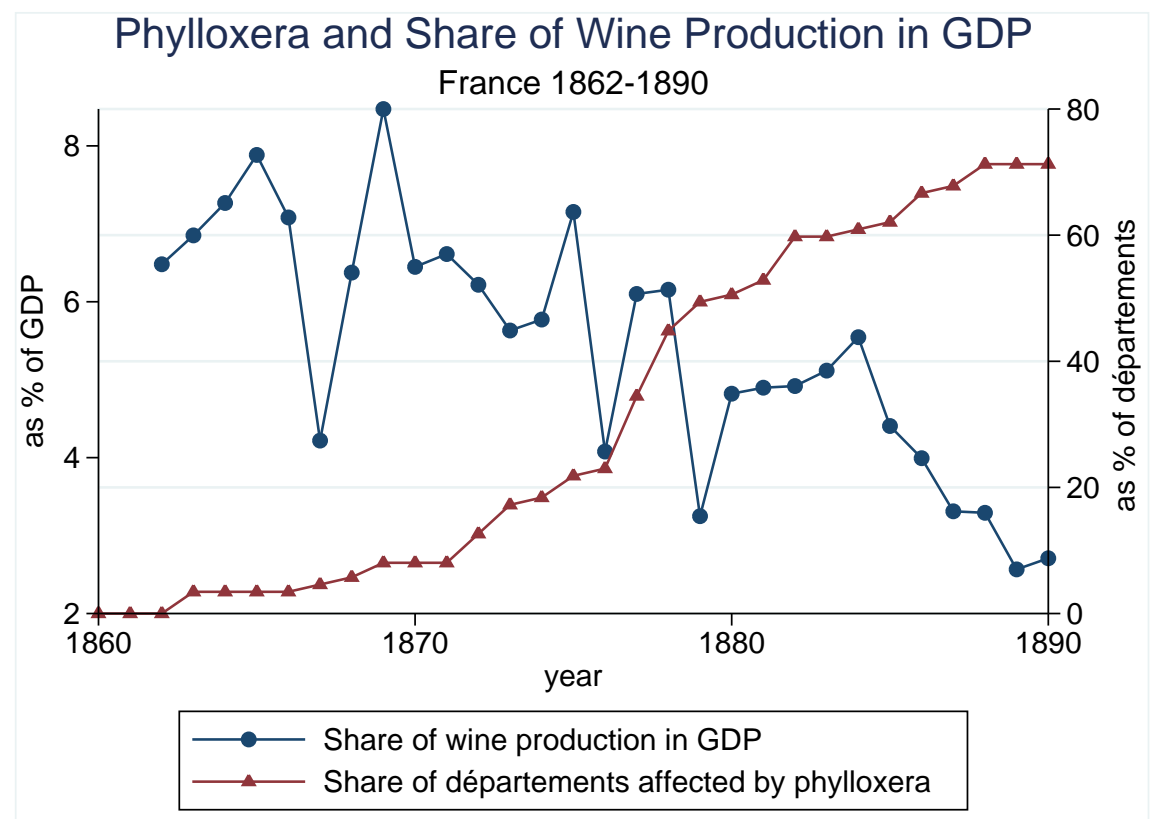

Figure 4: Revenues from wine production and the share of wine-producing districts infected by phylloxera between 1860 and 1890 (source: Bignon, Caroli and Galbiati, 2016)

of district GDP in others. On average wine production represented 9.2\% of GDP in wine producing districts. By 1890 the revenues from wine production had dropped to $2.75 \%$ of French GDP, see Figure 4. In some regions the impact of the aphid onto local economies was disastrous (Postel-Vinay, 1989) in particular as price increases did not compensate for the fall in quantity (Bignon et al., 2016). Figure 5 plots the distribution of the share of the district wine production as percentage of district GDP in 1862.

At the same time, the shock induced by phylloxera did not impact consumers' budgets as the consumption price of wine did not increase markedly for three reasons, see Bignon et al. (2016). ${ }^{9}$ First, wine imports increased sharply. Second, the practice of wine cultivation spread quickly to the (phylloxera free) French colonies in North Africa, notably Algeria. Third, various wine adulteration techniques were allowed to maintain the total quantity of alcoholic beverages created from the pressing of grapes. ${ }^{10}$

The impact of the phylloxera on agriculture was smoothed neither by fiscal nor monetary policy. The central bank was prohibited from lending against any assets that had been originated in the agricultural sector. Fiscal policy was of little help either: at the apex

\footnotetext{
${ }^{9}$ For example the price of wine in Paris was pretty stable during the whole period.

${ }^{10}$ The second wines (called piquette) were produced by adding sugar to the cakes that remained after the first pressing. These second wines were sold on the market in the 1880s.
} 
of the disease in the 1880s the state spent one million Francs a year on phylloxera-the equivalent of $0.7 \%$ of the French 1862 wine production-and this little money was directed toward scientific research (Loubere, 1978, p. 172). Moreover, no welfare programs such as unemployment benefits existed to absorb parts of the revenues losses. As a result the shock created by phylloxera on agriculture was transmitted to the other sectors of the French economy and decreased the other sectors' revenues.

Traditional credit markets helped smooth the shock during the first years. But the failures of farmers and wine growers fed back on notaries, and on the savers that had trusted them. Some notaries failed and savers shied away from investing in assets originated in the agricultural sector (Postel-Vinay, 1997, p. 286-7). In addition, the liquidity of mortgages and other long-term debts was especially hit, as defaults on mortgage interest payments reduced the liquidity of the secondary market for those debts Postel-Vinay (1997, p. 3256). Farmers turned to borrow from financial intermediaries such as local banks, but they were impacted by the crisis as well (Postel-Vinay, 1989).

The length of the episode (from 1863 to 1890) made it impossible for farmers to maintain consumption by drawing on their savings. It was very unlikely that farmers had been able to increase their saving in advance of the income shock. This would have required a clear understanding of how the disease would spread and of its cause, an issue that was not settled before 1875 (Gale, 2011, chapter 1). Even then, historical evidence shows that the new-found agreement on the cause of the disease did not make French peasants wiser when it came to using the spread of the insect over the territory as a signal for future losses. The literature identifies two reasons for this lack of foresight. Some peasants argued that the disease would be confined by nature to some regions, while others simply denied its existence, arguing that the disease could be avoided by taking good care of the vines (Gale, 2011, p. 52). Loubere (1978, p. 158) argues that such a blindness resulted from the policy of uprooting the diseased vines as a means to safeguard those still intact.

To sum up, the shock induced by phylloxera has several characteristics which provide for an ideal setting for analyzing the effects of variations in central bank eligibility. (i) Phylloxera was a sizable real productivity shock on the agricultural sector and was transmitted to the other sectors; (ii) The fact that phylloxera arrived in different districts at different moments in time allows us to analyze the effects of the crisis at a district level thereby increasing the number of observations and helping us to circumvent the small sample problem typical of other lending of last resort studies; (iii) It is reasonable to consider the disease as a temporary income shock on banks, services and industry, as a cure to the disease was finally found; (iv) The setting properly singles out the role of eligibility as fiscal policy and 


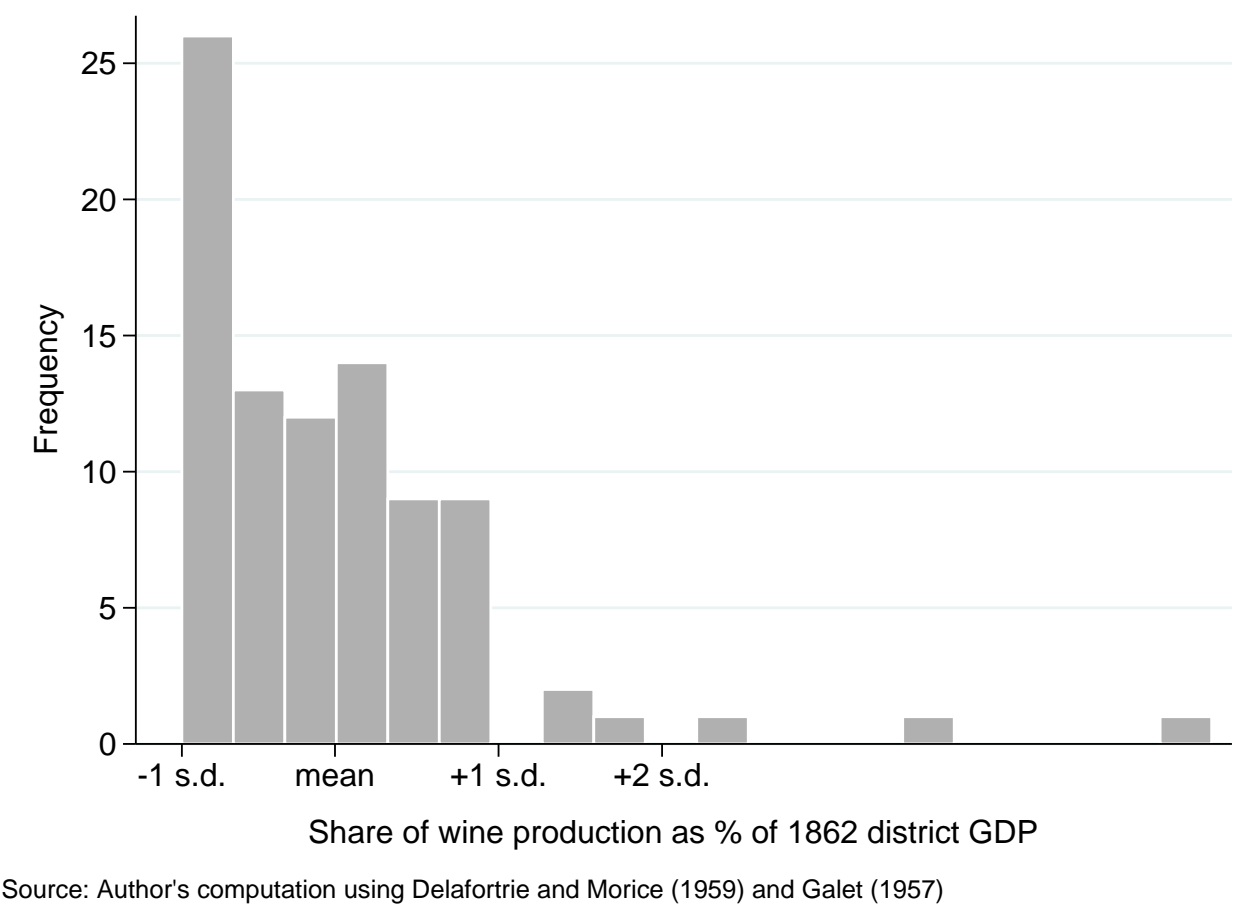

Figure 5: Frequency distribution of the share of wine production in the GDP of the district in 1862

other aspects of monetary policy were not changed in response to the shock; (v) The clearly external nature of the shock allows excluding reverse causality between eligibility and the economic crises caused by the disease.

\section{Data}

The dataset contains yearly observations on the variables of equation (1): the default rate $D R_{i t}$ (Section 4.1), yearly measures of the importance of the shock triggered by the spread of the phylloxera in each district shock $k_{i t}$ (Section 4.2) and measures of eligibility to the central bank and the two main deposit banks eligit (Section 4.3).

\subsection{Default rate}

For each district and each year, the number of defaults on debt repayment is known from the number of openings of a judicial procedure called failure (faillites in French). According to both law and jurisprudence this procedure aimed at protecting the equality of all creditors when the debtor proved unable to pay one of its creditors. The procedure 
allowed creditors to screen the value of the assets, to ascertain the validity of the liabilities (so as to avoid some creditors to be impaired by made-up claims) and to decide on whether the business had to continue being operated or not, in which case the monetary value of the assets was shared between the creditors. ${ }^{11}$

The definition of a failure in French law has a number of convenient features for our empirical design. First, the opening of a failure procedure was tied to illiquidity and not to insolvency. Indeed, the law stated that a failure procedure could be opened only after the observable recognition of a default. This was to prevent anti-competitive or political interferences with the running of businesses, where some competitors could have demanded the opening of a failure procedure with the only aim to drive a competitor out of business. In their comments of the law, legal scholars made it clear that a presumed state of insolvency in itself could not be taken as a motive for the opening of such a procedure since insolvency could only be decided after a proper screening of assets and liabilities of the firm. Therefore the law opted for a criterium that could not be manipulated easily by outside parties and no judge could force an (allegedly) insolvent but liquid firm to file for a failure procedure (Percerou, 1935). As a consequence, the number of failure procedures opened clearly identifies the number of defaults in a given location during a given year.

Second, the number of new openings of the failure procedure gives the appropriate measure of defaults in services and industry. The reason is that only traders qualified for the procedure, while workers and other non-traders such as farmers or lawyers were excluded. Frontiers between the different activities were easily drawn. A trader - commercant in the legal definition - was defined as an independent business earning revenues from the selling for profit of products and/or services. ${ }^{12}$ Defaults by workers or firms operating in the agricultural sector - farmers - were regulated in a different legal procedure. The distinction comes in handy here, because we are using an income shock to the agricultural sector to assess the effects of central bank liquidity support on the other sectors of the economy.

The number of defaults per district is known by counting the number of faillites openings during a year. The data appendix details the sources used to document them at the district level. It is worth noting that neither the definition of defaults counted as faillites by the administration nor the scope of businesses to which the law applied were changed during

\footnotetext{
${ }^{11}$ The creditors were assisted by a judge who had to keep the records of the events occurring during the procedure and to check the legality of the decisions taken by the creditors. The judge was assisted by an agent specialized in the screening of the assets and liabilities of the bankrupted firm. No creditor could opt out of the procedure before the creditors had voted on the outcome except by renouncing his claim.

${ }^{12}$ Examples include wholesalers, shopkeepers, insurers, bankers or manufacturers.
} 
the 19th century. To compute the default rate, we divide the number of defaults by the stock of firms in services and industry active during each year in each district. The number of firms in services and industry was retrieved from statistics on the French business tax (patentes). The business tax was paid by every trader, i.e. any business selling goods or services for profit on the market, which again encompassed all shopkeepers, wholesalers, factories, craftsmen, and banking and insurance firms. Like in the statistics on defaults, the agricultural sector was exempted. The appendix details the sources from which the number of tax-payers were retrieved. ${ }^{13}$

\subsection{Measures of the shock triggered by the spread of phylloxera}

A year before the phylloxera aphid was first spotted in France in the Gard district in 1863, wine was produced in 79 out of the 89 French districts. ${ }^{14}$ The 10 non wine producing districts were located in Brittany, Normandy and the North of France. All other districts produced at least some wine. The shock triggered by the phylloxera disease on the other sectors of the local economy varied with the share of wine in the district GDP. In 40 districts, wine production accounted for more than $15 \%$ of local GDP.

To account for the size of the crisis at the district level, we construct different specification of the variable $S h o c k_{i t}$ of equation (1) presented in section 2. Those specifications aim at measuring the size of the local economic crisis triggered by the agricultural disease in district $i$ during year $t$. The crisis varies with the importance of wine in the local GDP of district $i$ as well as the spreading of the disease within the district. As the speed with which the bug spread into each district varied across districts and time, no single lag structure can account for it. We present some measures of the propagation of phylloxera and its impact on wine production in section 5. To exclude that our results are driven by a particular choice of the lag structure we use three alternative variables to measure the size of the shock induced by phylloxera.

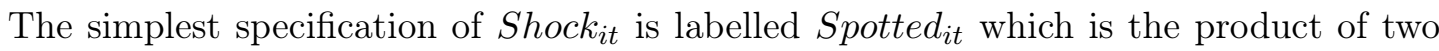
terms. The first term is a dummy that is set to 1 in any year between the first year the aphid was spotted in the district and the year of the implementation of the cure to the disease

\footnotetext{
${ }^{13}$ The business tax was paid at the level of individual establishments. To ensure the comparability of the number of defaults with the stock of firms eligible for the default procedure, we have collected the number of patentes payers, i.e. the number of firms that paid the tax, and not the cote des patentes which measures the number of branches of business units paying the tax.

${ }^{14}$ Three districts had to be dropped from our analysis because some data was missing for them, leaving 86 districts in the sample.
} 
in 1890. In any year before the aphid arrived in the district and after the implementation of the treatment, we set this dummy to 0 . In order to account for the different importance of wine for the economy of district $i$, the dummy is multiplied by a second term, which is set equal to the share of wine production in the 1862 GDP. As a result, Spotted it $_{\text {is }}$ equal to a constant term during the years phylloxera was present in district $i$ and zero otherwise. Table 1 presents the descriptive statistics.

An alternative measure of the size of the local economic crisis is the variable labelled impactdummy $_{i t}$ that controls for the significant time that could have passed between the first spotting of the aphid in the district and the moment at which it had led to widespread devastation of vineyards. In order to account for this, we use a dummy variable constructed by Banerjee et al. (2010). The dummy is set to 1, if the two following conditions are fulfilled. First, the aphid is present in the district. Second, wine production has fallen below the level reached during the last year before the arrival of phylloxera. As no direct information is available on the spread of the aphid within each district, the second condition aims at capturing that phylloxera must have spread sufficiently widely to have had an impact on wine output. Again, the dummy is set equal to 0 after the implementation of an effective treatment in 1890. Like in the case of Spotted $_{i t}$, the dummy is multiplied by the share of wine production in the 1862 GDP in order to account for the different weight of wine in local economies. As a result, impactdummyit is equal to a constant term during the years when both phylloxera was present in district $i$ and after wine production had declined relative to the pre-phylloxera benchmark level before 1890 and is zero otherwise.

A third alternative, which is our preferred variable, is labelled impactvolume $i t$ which is constructed as a continuous version of impactdummy $y_{i t}$ by taking into account the actual decline of wine production during the period when phylloxera depressed wine production. To construct the measure, we use again a variable constructed by Banerjee et al. (2010). Our variable impactvolume $_{i t}$ is the product of impactdummy $y_{i t}$ and the percentage decline in wine production relative to the level in the last year before the phylloxera was spotted in a district. Unlike Spotted $_{i t}$ and impactdummy it $_{i t}$ that are either zero or a constant, impactvolume $_{i t}$ varies with the actual decline in wine production during each year between the arrival of the disease in the district and the year 1890 and can thus take best account of the district-specific speed with which phylloxera was propagated.

\subsection{Measures for the eligiblity to the lender of last resort}

To measure the extent of access of local agents to the facilities offered by the Bank of France and the big deposit banks, we use two alternative specifications of eligit, which 
are constructed for both the Bank of France and the deposit banks. The first is labelled branches $\#_{i t}$ and uses simply the number of branches operated by either the Bank of France or the deposit banks within each district $i$ during year $t$. Taking the simple number of branches is justified given that French districts were all of roughly equal size and had been designed in 1790 such that every point within the district was within a one-day horse ride from the district capital. In case more densely populated districts needed more branches to offer the same degree of access to the banking system, we also use an alternative measure labelled branchescap $i t$, which adjusts the number of branches for the population of the district.

\section{Accounting for the spread of the phylloxera}

Before presenting the results of our regressions, this section takes a more in-depth look at the dynamics of the spreading of phylloxera and how the different definitions of the variable $S h o c k_{i t}$ presented in section 4.2 can capture these dynamics. The shock variable $S h o c k_{i t}$ has to properly account for two dimensions: First, the date of the arrival of phylloxera and two, the severity of the shock on the local economy. While the year when phylloxera was first spotted in each district is well known, the time it took the aphid to spread over the district is not. Historians have noted that it took quite some time for the aphid to destroy a significant proportion of the vineyards in a given district and, thus, to potentially affect other sectors in the economy. In addition, historical evidence indicates that the speed with which phylloxera spread across districts varied considerably. Some feeling for the dynamics involved can be obtained by running the following regressions along the lines of Wolfers (2006), which allow the impact of phylloxera to evolve over time:

$$
\text { Lprodwine }_{i t}=\alpha+\sum_{i \geq 1} \alpha_{i} \text { Infect }_{i}+\delta_{t}+\alpha_{i}+\nu_{i} \cdot t+\epsilon_{i t},
$$

where Lprodwine $_{i t}$ is the logarithm of wine production in hectolitres in district $i$ during year $t$. Infect $i$ is defined for every district as a function of the first sighting of phylloxera in the district: The variable Infect ${ }_{1}$ is set to 1 in the first year after the arrival of phylloxera in the district, Infect ${ }_{2}$ in the second year and so on. Therefore $i$ takes value between 1 and (at most for the district contaminated in 1863) 27. To control for structural differences between districts and shocks at the national level all regressions include time $\delta_{t}$ and district $\alpha_{i}$ fixed effects. District specific time trends $\delta_{t} * \alpha_{i}$ capture potential differences in the long-run evolution of wine production across districts. Finally, residuals are clustered at the district level, i.e. each regression controls for correlation among the observations of a given district. 


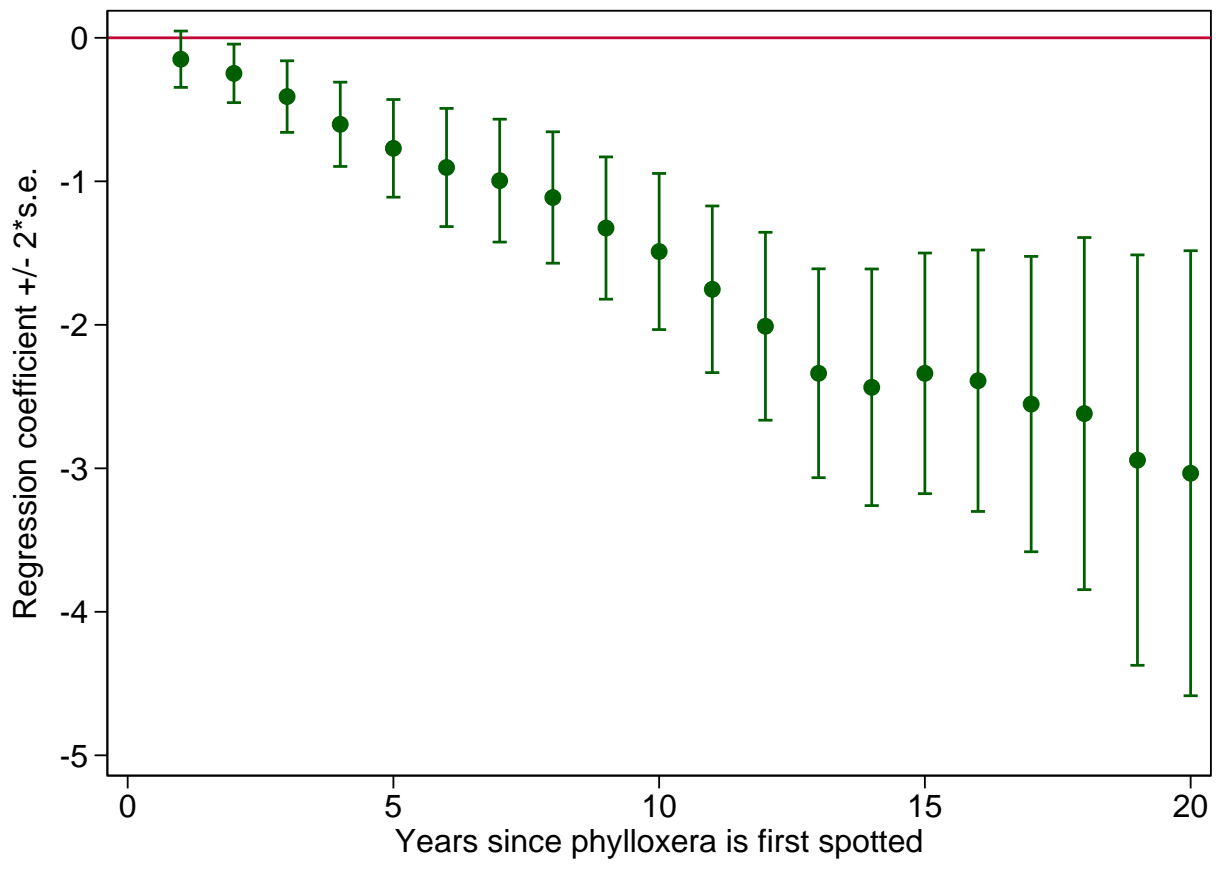

Figure 6: Dynamic effect of the spread of the phylloxera on wine production, 1863-1890

The coefficient and standard errors are plotted on figure 6. Inspection of the level reveals that on average phylloxera started to have a significant negative effect on wine production only four years after the first sighting of the aphid in a district.

A similar analysis can be undertaken for the relationship between the spread of phylloxera and local economic distress by studying the dynamic impact of the local importance of the crisis triggered by phylloxera on the default rate of non-agricultural firms. In this case, the dependent variable is a pure measure of the indirect impact of the shock on the services and industrial sectors. The following regression equation checks that the negative productivity shock on agriculture triggered an increase of the default rate in banking, services and industry.

$$
D R_{i t}=\alpha+\sum_{k \geq 1} \alpha_{k}\left(\text { Infect }_{i} * \text { Wine }_{i}^{1862}\right)+\delta_{t}+\alpha_{i}+\nu_{i} \cdot t+\epsilon_{i t} .
$$

where $D R_{i t}$ is the default rate in district $i$ and year $t$ and $W i n e_{i}^{1862}$ is the share of wine in the district GDP a year before Phylloxera was first spotted in France. All other variables are defined as in the regression above. All the residuals are clustered at the district level.

Figure 7 plots the evolution of the regression coefficient $\alpha_{k}$ and its confidence interval. It shows that the shock created by the phylloxera significantly increased the default rate of firms in services and industry and that the impact increased over time. The coefficient 


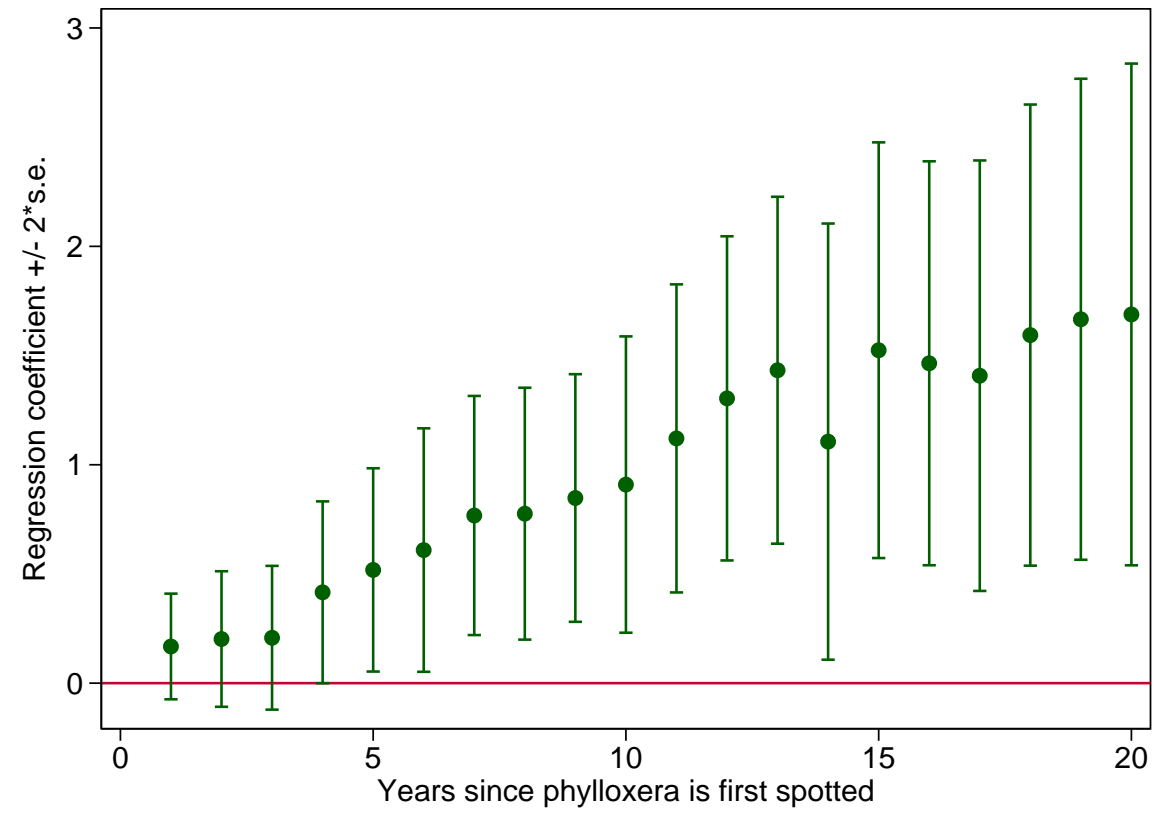

Figure 7: Dynamic effect of the spread of the phylloxera on district default rates of services and industry, 1863-1890

becomes significantly different from zero five years after the aphid was first spotted in the district, and one year after phylloxera had led to a significant decrease in the wine production of the infected district.

Together, both results show that in the absence of any proper treatment to prevent the vines from dying, phylloxera led to a sharp decline in wine production, triggering a sufficiently high negative shock to the productive assets of farmers so as to cause local (macro) economic crises in the affected districts. The relatively long time it took for phylloxera to significantly affect local wine production and broader economic conditions as well as differing size of the impact, as evidenced by the relatively wide confidence intervals around Infect $_{i}$, help to better assess the relative merits of the different specifications of Shock $k_{i t}$ presented in section 4.2 .

Spotted $_{i t}$ is set equal to 1 from the first sighting of phylloxera until 1890, when a reliable treatment of phylloxera was found, while impactdummy $y_{i t}$ combines the sighting of phylloxera with a fall in wine production, which could take several years as shown in figure 6. Impactvolume $i$ finally is allowed to vary from year to year in response to the fluctuations in production induced by phylloxera. The advantage of this specification is that because of climatic and geographical factors, wine production in some districts may have 
been more affected by phylloxera than in others. Moreover impactvolume $i$ accounts better than the other two specifications for the impact of phylloxera on local income. The following baseline regressions thus use impactvolume $i t$ as explanatory variable, while spotted $_{i t}$ and impactdummy $y_{i t}$ are employed to check the robustness of the results.

\section{Results}

We present the main results in section 6.1 , check the robustness of the main results in section 6.2 and discuss the exogeneity of the eligibility measure to both the default rate and the propagation of phylloxera in section 6.3.

\subsection{Main results}

Equation (1) relates the default rate to central bank eligibility and a number of control variables. The results of the estimation of equation (1) that use impactvolume as the crisis variable and the number of branch offices operated in the district branches\# as the measure for eligibility are reported in table 2 . The first column reports the baseline estimate on the period 1826 to 1913, including year and district fixed effects as well as district-specific time trends. Residuals are clustered at the district level. The second column adds control variables. Column (3) restricts the estimation to the sub-sample of wine-intensive districts while column (4) looks at the sub-sample of years during which no cure to the phylloxera were available, i.e. to 1863 to 1890.

The key variable of interest ist the interaction variable between the depth of the crisis and the eligibility for the central bank. In column (1) it is negative and statistically significant at the $1 \%$ level. This implies that an increase in the eligibility for the central bank significantly reduced the default rate when the phylloxera crisis hurt the district. This result is consistent with the fact that the central bank refinanced the economy by buying bills of exchanges payable by non-agricultural firms and guaranteed by the banking sector. The phylloxera crisis variable significantly increased the default rate of the industry, financial and services sectors, which is consistent with the view that the central bank did not try to avoid the default of all firms. The eligibility variable is usually negative, which is consistent with the fact that the Bank of France operates the payment system of bills also in normal times. However the coefficient is usually non-significant, suggesting that it was mainly in times of crises that eligibility mattered.

Adding additional controls in column (2) does not alter these results. National rediscounting banks such as Crédit Lyonnais and Société Générale have no impact on the level of 
the default rate, and when phylloxera arrived, they even appear to have restricted lending pro-cyclically, thereby increasing the default rate of the industrial, services, and financial sectors. In any case, the coefficient on the interaction term is only weakly significant. The number of firms per 1,000 inhabitants and population density both proxy for local economic development and differences in the evolution of economic structures across districts (structural difference that do not change over time are already captured by the district fixed effects in the baseline regression). The coefficients on both variables are negative and statistically significant, implying that higher developed districts featuring more entrepreneurial activity were also ceteris paribus those with lower default rates. ${ }^{15}$

The results are therefore consistent with the view that eligibility for central bank operations prevented to some extent the agricultural crisis to spill over to solvent but liquidity constrained firms in the rest of the economy. To assess the economic significance of this result, we perform the following counterfactual exercise. We use the coefficients of the regression of table 2 column (2) to predict the evolution of the default rate in two counterfactual scenarios in which the Bank of France would have (1) operated no branches during the period of the spread of the phylloxera (i.e. set $E l i g_{i t}^{B o F}=0$ for all $i$ and $t$ ) or (2) would have had opened in the year of the arrival of the phylloxera on the French territory in 1863 all the branches that it operated in 1913 (i.e. set $E_{i i} g_{i t}^{B o F}=E l i g_{i 1913}^{B o F}$ for all $i$ and t). The resulting counterfactual default rates for all districts are then aggregated to a national default rate for France. Figure 8 compares the actual evolution of the default rate for France with the default rates in the two counterfactual scenarios. In the complete absence of Bank of France branches the default rate would have fluctuated at levels roughly $10 \%$ to $15 \%$ higher than was actually observed in the late 1870s, early 1880s. A reduction in the default rate by $10 \%$ to $15 \%$ is highly economically significant as there were many reasons for defaults other than phylloxera and that could not be alleviated by central bank liquidity support. Conversely, the bank would have been even more successful in counteracting the crisis triggered by phylloxera had it had its 1913 network already in place in 1863.

\subsection{Robustness checks}

Tables 3-5 provide estimates with alternative specifications for the two key explanatory variables, the measure for central bank eligibility and the measure for the economic impact of phylloxera.

\footnotetext{
${ }^{15}$ The variable farmsize $*$ shock accounts for regional variation in the size of agricultural business and the structure of wine growing that might lead to a different impact of phylloxera on regional income and liquidity provision. The coefficient is never statistically significant.
} 


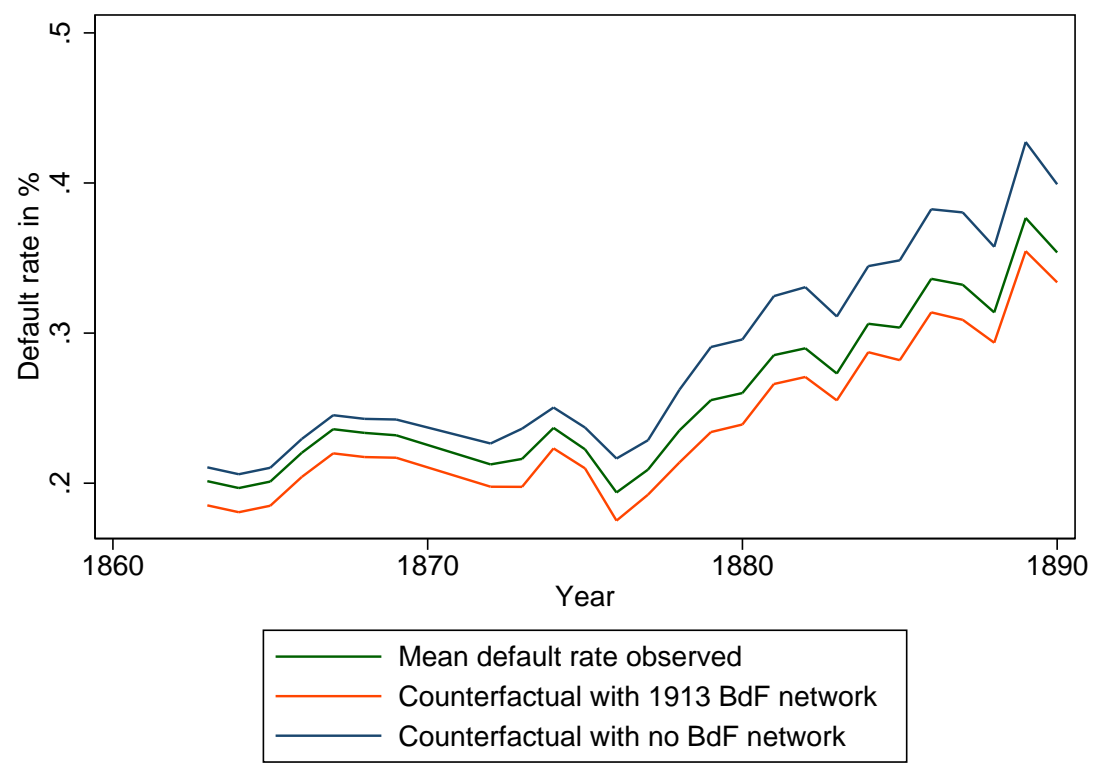

Figure 8: Observed and counterfactual default rates comparing the impact of having no branch or of having opened in 1863 all the branches operated in 1913 compared to the actual data

Alternative specifications for eligibility. The estimations reported in table 2 reproduce those in table 1 with the only difference that access to the central bank as well as to the national deposit banks is now measured by the number of branches per capita branchescap. As branchescap is smaller than branches\# the coefficients on the eligibility variable and the interaction term are bigger now. As can be seen, however, sign and statistical significance are unaffected by this alternative specification of eligibility.

Alternative specifications for the shock. The same is true when alternative measures of shock $_{i t}$ are used. Table 3 gives the results when instead of using impactvolume $i t$ the economic effects of phylloxera are measured using Spotted $_{i t}$; table 4 when using impactdummy it $_{\text {. }}$ Again the signs of all relevant variables are unaffected, both in the most parsimonious specification in columns (1) and the specification including additional controls in columns (2). The main difference to the specification using impactvolume $e_{i t}$ and reported in table 1 is that the coefficient on the shock measures, while correctly signed, is now sometimes not statistically significant. This result is not surprising given that both Spotted $_{i t}$ and impact $_{d} u m m y_{i t}$ are less precise measures for the impact of phylloxera than impactvolume $i t$. Importantly for the argument on the role of the Bank of France in mitigating the negative effects of phylloxera, however, the interaction term is correctly signed and highly significant with 
both alternative shock measures.

Restriction to wine-intensive districts only. In all tables 1-4 columns (3) provide an alternative specification excluding districts with only a small or no wine producing sector. We define as wine intensive all districts, where wine accounts for more than $15 \%$ of the total cultivated area. The main results are unchanged. The coefficients in front of the shock variable and the interaction term do not change or increase slightly and their level of significance remains unaffected or even increases somewhat.

Shorter time period. The second sub-sample looks only at the years from the arrival of phylloxera in 1863 until the identification of a cure in 1890. Even though the total number of observations is thus drastically reduced, the coefficients, reported in columns (4) of tables $1-4$, are still correctly signed and the significance of the coefficient of the interacted terms is maintained.

Spatial autocorrelation. A last set of robustness checks concerns potential spatial correlation. The results of the estimation of equation (2) are given in table 6 . We focus on the different eligibility and shock measures in the parsimonious specification and include the additional controls only when estimating the baseline model with impactvolume $i t$ as shock and branches\# as eligibility variables. The inclusion of a spatial error term does not change the magnitude and statistical significance of the coefficients. A comparison of the coefficients in table 5 with those in the corresponding specifications without spatial error term in tables 1-4 shows that most coefficients and standard errors remain completely unchanged. Spatial correlation has thus no bearing on the results presented above.

\subsection{Exogeneous branching to default rates and phylloxera}

In this section we exclude that the decision of the Bank of France to open new branch offices (the eligibility variable) was driven by the concern of alleviating the effects of phylloxera or conversely that the Bank hesitated to open branches in districts hit by the phylloxera crisis. We provide narrative and econometric evidence that branching was not influenced by phylloxera and that the estimated coefficients on the impact of access to the Bank of France on the default rate are not over- or underestimated.

Historians explain the gradual extension of the branch network of the Bank of France visible in figure 1 as the outcome of both political and competitive pressures (Pose, 1942; Bouvier, 1973; Plessis, 1985). After having taken over all provincial note issuing banks in 
1848 (Gille, 1970), the Bank of France enjoyed a monopoly of note issuance in the cities in which it operated a branch. This monopoly was only briefly contested by the Pereires brothers in the 1860s (Cameron, 1961; Domin, 2007). Beginning in the 1860s, however, some commercial deposit banks, most notably Société Générale and Crédit Lyonnais, created their own large networks, soon covering the entire territory of France (Bouvier, 1973; Pose, 1942). These banks collected significant amounts of deposits that they employed in local discounting, thereby draining business away from the Bank of France (Lescure, 2003, p. 136-7). As competition for good bills was fierce in the larger cities, the Bank of France reacted by expanding its own network, refinancing smaller regional and local banks in more remote places (Nishimura, 1995).

A second motive was politics. The charter-in particular the note issuing monopoly-was granted to the Bank for specified periods of time (Ramon, 1929). Whenever the charter came up for renewal, the Bank needed political support from the government and among lawmakers in parliament (Dauphin-Meunier, 1936). Extending services at existing branches or opening new branches was a good way to buy support at the local level. As a consequence, all renewals included clauses that lead the Bank to extend its network. The renewing of the privilege of 1857 required the Bank to open at least one branch in every district, without setting a deadline. This was done in 1873, when the Bank was instructed to cover all districts by the beginning of 1877 at the latest (Plessis, 1985, p. 199-201). The charters of 1897 and 1911 again contained clauses requiring the opening of further branches (Pose, 1942). In addition, according to Lescure (2003), from the 1880s onwards, a new generation of bank officers saw the role of the Bank as being at the service of the public, and hence an obligation to ensure equal access to its services for all citizens of the country.

Accordingly the Bank of France not only expanded geographically, but implemented significant simplifications in the access to its discount and giro (overdraft) facilities (Leclercq, 2010). On the other hand, the opening of a branch was costly. In the 1890s the Bank estimated the set-up costs to be about 160,000 Francs, and the annual operating costs at 36,000 Francs for a small branch, at a time when the hourly wage of a qualified blue collar worker rarely exceeded 1 franc. Given the high set-up costs the Bank had to consider seriously the long-run viability of the new branch by obtaining information on the likely volume and risk characteristics of the local demand for (re)discounting. The opening of a branch also took time. The Bank had to find a building and recruit director and staff as well as the members of the committee that examined the bills submitted to discounting (comité de censure). Branch office opening typically required a lead time of one year and could hardly had been used to address an acute crisis. 
As can be seen in figure 1, the network expanded gradually until the mid-1880s and was then extended significantly after 1897 and 1911. This pattern fits well with both mounting competition from commercial banks in the 1860s and the political economy of rechartering. To check the validity of this interpretation, we provide a formal test by estimating a duration model. The duration model studies the entire population of urban agglomerations in France of at least 2,500 inhabitants to estimate which characteristics were significantly associated with the opening of a branch by the Bank of France. The goal is to explain the time it took to the opening of a branch office. Duration analysis is appropriate as the Bank never closed a branch, i.e. the status of a city can only change from not having a branch to having one. This gives 782 potential cities among which the Bank of France could have chosen to operate branches in $1880 .{ }^{16}$, of which 140 were selected by the Bank to open an discount facility office between 1830 and 1913. The regression model reads as follows:

$$
\begin{aligned}
\text { Opening }_{i j t}=\alpha & \cdot \text { Shock }_{j, t-1}+\beta \cdot \text { Pop }_{i, j, t-1}+\gamma \cdot \text { DR }_{i, t-5_{t}-1}+\eta \cdot \text { Bank }_{i, j, t-1}+\lambda \cdot \text { Surface }_{i, j} \\
& +\delta \cdot \text { Popdistrict }_{i, j, t-1}+\lambda_{1} \cdot \text { CapCity }_{i j}+\lambda_{2} \cdot \text { BoFpresent }_{j t-1}+\epsilon_{i j t}
\end{aligned}
$$

Equation 5 explains the opening of a branch in a city $j$ of district $i$ during year $t$ where Opening $_{i j t}=1$ if a branch was opened in the city during year $t$ and else is set equal to 0 . Previous historical research summarized above suggests the inclusion of both political and economic factors as explanatory variables. In addition we include both an indicator for the presence of phylloxera and the default rate to see whether the spread of the disease and its economic consequences affected the Bank's behaviour. Because it took at least a year between the decision to open a branch and its opening to the public, all right-hand side variables are lagged by one or two years depending on the specification.

Economic factors accounted for the attractiveness of establishing a discount business in a given city. First, population $P_{o p_{i, j, t-1}}$ of the city is a proxy for the size of the local economy. The population of the district Popdistrict ${ }_{i, j, t-1}$ measures economic activity in the wider catchment area of a potential branch office, while the inclusion of the surface of the district surface $_{i, j}$ corrects for low or high population density. Competitive pressure is accounted for by a categorical variable $B a n k_{i, j, t-1}$ indicating whether a deposit bank operated a branch during the previous year in the city or not.

The political variables capture the pressure coming from the need for a regular renewal of the charter. The 1857 charter, reinforced in 1873, required the Bank to open at least one branch in every district. As a consequence, the probability of a branch opening

\footnotetext{
${ }^{16}$ The Bank never opened branches outside urban agglomerations Bazot (2014); Jobst (2010). The number of cities levelled between 727 in 1851 and 782 in 1913.
} 
should be higher in districts if the district has no branch office yet. The dummy variable BoFpresent $_{j t-1}$ is zero if the Bank of France has no branch office in this city or in any other city of the district and one otherwise. Given that the 1857 charter of the Bank of France forced the Bank to open a branch in every district before 1878, it is likely that the bank would do so in the economically most important city of the district. This is accounted for by the variables poprank 1 , poprank 2 , etc. which are set to one for the largest, the second largest, etc. city in the district and zero otherwise. Dummy CapCity ij indicates whether the city is the capital city of the district, i.e. the seat of the central government representative (prefecture) ${ }^{17}$. It accounts for the possibility that political pressure would lead to the opening of a branch office in a politically rather than economically important city.

Finally we include two variables that look at the impact of local economic shocks and phylloxera in particular. Shock $k_{j, t-1}$ is a dummy indicating whether the district was contaminated by the phylloxera during the previous year. The default rate variable $D R_{i, t-5_{t}-1}$ is included to check whether a local economic crisis increased or decreased the Bank's willingness to operate a local facility. To smooth year-on-year variations the default rate was averaged over the last five years from $t-5$ and $t-1$. Because of data unavailability at the city-level, the default rate and the shock variable are measured at the district level.

Table 7 presents the results of the estimations with a 1-year lag and table 8 those with a 2-year lag. Coefficients larger than one imply that the variable increases the probability a branch being opened. The district default rate and the phylloxera crisis variable are not significant, independently of whether they are included alone or together and whether further controls are added or not. In terms of economic factors, both higher district population increases the likelihood of a new branch being opened as well as the fact that one of the two main national deposit banks was already operating a branch. The coefficient on the absolute population of the city itself is not significant; however, population rank is. The probability of a branch being opened in the second largest city of the district is almost half of that in the largest city and probability declines rapidly when we turn to the third or fourth largest cities. The significance of rank reflects the tendency of the Bank of France to open branches in the biggest city in the district given the constraint that Bank had to open at least one branch in every district. As soon as one branch had been opened, the probability of further branches being created declined significantly, as evidenced by the

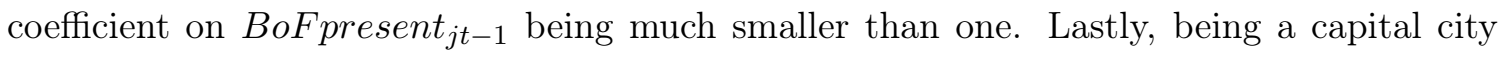
increases the probability of a branch opening by a factor of close to 5 . The coefficients are

\footnotetext{
${ }^{17}$ District capital cities did not change during the 19th century.
} 


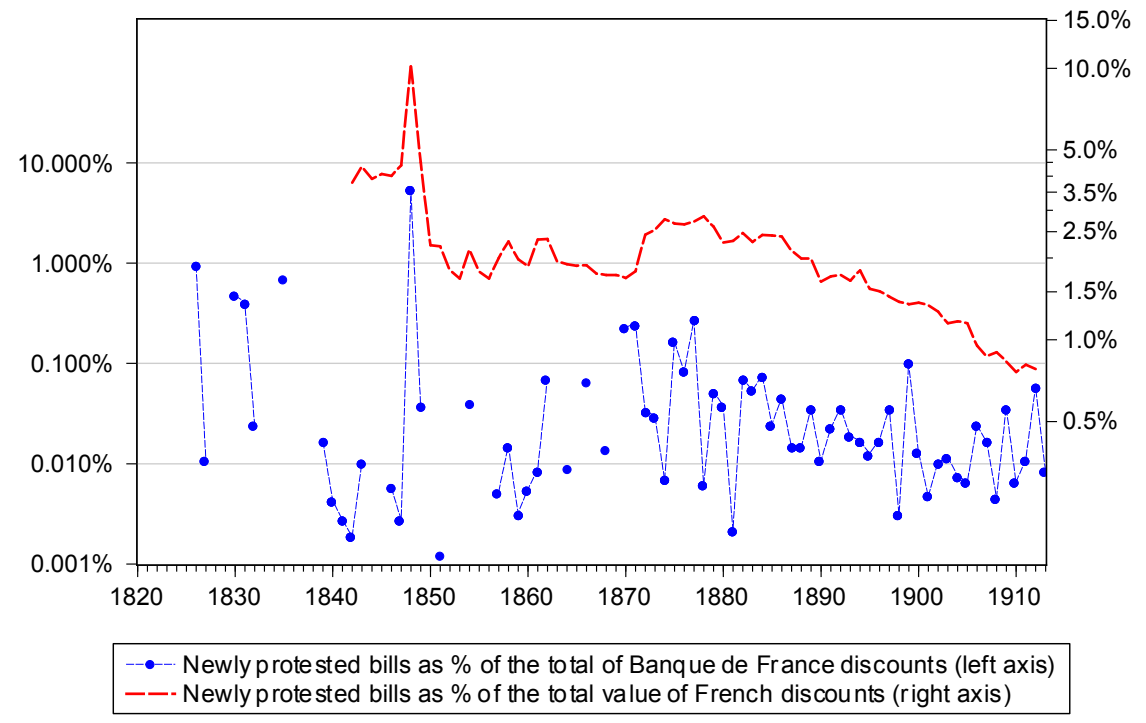

Figure 9: Unpaid bills at maturity as percentage of the discount activity of the Banque de France and of all the stamped bills issued in the economy (1860-1913)

unaffected with a 2-year lag, see table 8 .

All in all the results are consistent with the historical narrative that the decisions by the Bank of France to open branch offices were unrelated to either the default rate or the spread of the phylloxera. It is likely that the high setup cost of branches and the difficulty to monitor the local discounting activity were a strong motivation for the Banque de France to avoid opening branches with the sole goal of mitigating temporary shocks.

\subsection{Lending of last resort and the absence of bail-out}

In this section we ask whether the central bank suffered any losses on its discount activity in distressed districts. To measure the risk taken by the Bank in its discount policy, we have collected the amount of protested bills discounted by the Bank of France, where protested means that the bills were not paid when due. Figure 9 plots the percentage of the Bank's portfolio and compares it to the percentage of protested bills at the economy-wide level. Inspection of the graph reveals that the proportion of bills unpaid at maturity in the Bank of France portfolio stands at $0.015 \%$ during the period between 1820 and 1913. This level was much lower than the ratio at the economy-wide level, which averaged at $2.18 \%$ during the period from 1842 to 1912 . 
This is no surprise given the monitoring of risk that the Bank of France adopted when discounting bills and the screening of the counterparties involved. Because the Bank did purchase the bills of exchange outright, any default on payment at due date had a direct impact on the dividend. As a privately owned company traded on the Paris stock exchange, the Banque de France had a keen interest to screen the bills carefully in order to minimize its exposure to default so as to protect profitability.

As already pointed out before, the safety and liquidity of bills of exchange hinged on the number and quality of the endorsers. By putting his signature on the back of the bill, every endorser became liable to pay the bill at maturity if the drawee was in default. ${ }^{18}$ The guarantee was easy and quite cheap to call on. ${ }^{19}$ The percentage share of unpaid bills plotted in figure 9 relates to the cases where a guarantee was called, not to the share of bills to be written off. While the procedure could take a couple of weeks, ultimately losses were close to zero.

To limit the risk of losses the Bank of France applied strict rules. The law required the Bank to discount only bills guaranteed by at least three notoriously solvent persons. Moreover the bank screened its counterparties carefully through local discount committees which had good knowledge of the businesses of presenters of bills. The activity of the committee was in turn monitored by the portfolio committee composed of shareholders of the Bank and ultimately examined by three censors elected by the shareholders assembly. In addition, bank inspectors visited local branch offices at least once a year to assess and crosscheck the quality of information on presenters and endorsers and to check whether the director of the branch did not overstep his responsibilities by bypassing decisions of the local discount committee. Together these precautions explain why the Bank suffered less from non-payment than the average discounter in the economy. Also there is no correlation between the spread of the phylloxera and the provisions for losses in the portfolio. The decrease of the default rates caused by a higher number of Bank branch offices is not explained by a central bank bail-out of insolvent borrowers.

\footnotetext{
${ }^{18}$ The law and jurisprudence carefully organized the transfer of ownership of bills that occur with each act of discounting. Each discount left the previous owners with a joint liability vis-á-vis the purchaser of the bill (the discounter). Each discounter signed the bill in an acknowledgement of his commitment to pay the bill in case of default by the drawee.

${ }^{19}$ It only required the ascertainment of the default on the payment in due time by a bailiff, a notary or two witnesses at the moment the bills fell due and allowed the owner of the bill to invoke the guarantee of the last endorser, asking him to pay in lieu of the initial payer, and so on up to the drawer of the bill.
} 


\section{Conclusion}

The present article provides an empirical analysis of the beneficial effects of broad access to the central bank as lender of last resort. Our goal is quantitative. We use a quasi-natural experiment that occurred in France in the 19th century to document that broad eligibility criteria helped stabilizing economies hit by economic shocks. The empirical analysis is based on a newly assembled dataset tracing the economic evolution of all French districts during the period from 1826 to 1913.

To isolate a source of exogenous variation the identification strategy exploits the peculiarities created by a constraint on the implementation of monetary policy. In the 19th century the eligibility to the discount window of the Bank of France was directly conditioned on the existence of a local facility by the Bank allowing it to collect payments when due. This feature allows exploiting the spatial dimension of central bank access, as we can argue that the opening of branches by the central bank was exogenous to both to the various shocks and to the default rate.

To test for the consequences of access to central bank lending (or the absence thereof) on economic outcomes, we study a negative productivity shock triggered by an agricultural disease, phylloxera. Lower incomes by farmers translated into an income shock for firms in other sectors increasing the demand for credit by solvent firms to smooth the consequence of the crisis. As entrepreneurs had little incentive to strategically default, the main problem for the lender was to screen the solvency of the firms hit. By discounting, the central bank liquefied the wealth of private agents, i.e. transformed assets that could not be traded or only at a high cost into liquid banknotes or reserves that allowed borrowers to pay their bills. The paper shows not only that the increased volume of money distributed by the lender of last resort helped smooth the consequences of the crisis but that broad access to the central bank was particularly helpful. At the same time, the Bank of France did not bail out the private sector by taking over worthless assets.

The fact that the extension of eligibility via the creation of new branch offices was not driven by stress in the financial sector but caused by structural reasons also implies that the positive results of the extension of eligibility were not the result of an explicit policy by the bank. The argument however adds a new channel through which central bank branching might have affected the real economy. More generally, we think that eligibility of counterparties and assets deserves more attention. If there is any lesson to draw from this past experience in terms of today's monetary policy, our results stress the importance of the framework in which the central bank implements its monetary policy in times of crisis. 


\section{A. Appendix}

French districts In 1826 France was composed of 86 districts with a size equivalent to the average size of a U.S. county. Two main changes in the frontiers of France make the panel slightly unbalanced. First, in 1860 France incorporated three new districts with the annexation from Italy of the Savoy and Nice which brought the total number of districts to 89. The defeat in the war against Prussia in 1871 ended with the loss of two districts in Alsace and of half of the Meurthe district and half of the Moselle district. The remaining parts of the latter districts were merged to form a new district, Meurthe et Moselle. Part of the Alsatian district "Haut-Rhin" remained French in the post 1871 period, but was dropped from our sample. Hence after 1872 France contained 86 districts. The quality of the data during the war years of 1870 and 1871 led us to drop the observations for these years.

Population Data were taken from Bignon et al. (2016).

Wine production and phylloxera Data on wine come from Galet (1957). We use data collected by Banerjee et al. (2010) on the years during which phylloxera was spotted in each district and on the variables of wine cultivation and wine production.Galet (1957) provides no information on the presence of the phylloxera in two districts, the Ardéche and the Creuse. They were dropped from the regression analysis during the whole period.

District GDP in 1862 We used Delafortrie and Morice (1959) to compute the share of wine production as a percentage of local GDP during the year just before phylloxera appeared.

Central banks and banks Statistics on the activities of the Bank of France were taken from the annual report to the General Assembly of the Shareholders. A typical report indicated where the branches of the Bank were operated during the year and the volume of outright purchases done. The annual reports also reported data on protested bills at the national level. Information on the branch offices operated by the two most important national branch banks, Société Générale and Crédit Lyonnais, comes from Billoret (1969) and the annual reports of Société Générale.

Defaults of firms in the industrial and service sectors Few corrections have to be made to those data since the definition of the scope of firms that may default under the procedure faillites did not change during the 19th century, nor did the definition of the 
failure, i.e. the fact that the manager of a unit defaulted on his payment obligations. Yet some innovations introduced in the course of the century require some assumptions. The most notable change was the 1889 law that introduced a new process through which disputes over the payment of debt could be settled, the liquidation judiciaire. This new procedure was said to have been motivated by the intention to lower the failed debtor's shame and social stigma associated with filing for bankruptcy. Therefore a strict reading of the letter of the law would have led to exclude this procedure from the actual number of bankruptcies. But following the letter of the law would have also created a spurious decrease of the default rate, as a huge substitution occurred between the traditional failure procedures and the new one. Hence following all previous scholars, the failure numbers include for the 1889-1913 period both the number of faillites and the number of liquidations judiciaires.

The stock of operating firms in services and industry Most previous scholars have used and commented the absolute number of defaults, without any correction for the potential increases in the number of firms operated (Jobert and Chevailler, 1986). We use a fiscal source (the Patente) to document the population of firms in services and industry. The firms eligible to the payment of this tax were also those that were eligible to the default procedure that we use to compute the default rate, as noted in the 1880 s by the ministry of Justice in the introduction to the Compte général de la justice civile et commerciale. Loua (1877) and Limousin (1900) also used this tax to measure default rates. Corrections must be implemented to correct for the spurious changes created by a number of tax reforms that altered either its tax base or the population eligible to its payment. The Patente was a tax introduced in 1791 that survived the whole 19th century. It had to be paid by any type of businesses selling goods or services on the market. These included (among others) shopkeepers but also wholesalers, any type of factories, craftsmen and banking and insurance firms. The agricultural sector was exempted from paying it, as were the legal professions. Data on the number of patentes paid at the district level were collected in the national archives in the file F20 423 titled "Ministéres des finances, relevés des contributions directes" for the years 1826-1844 as kept by the National Archives in Paris. The data on the number of firms paying the tax for the years 1845 to 1872 and 1881, 1882 and 1889 are from the Compte général des recettes de l'état as kept in the National Library in Paris. The numbers for the years 1873 to 1899 and 1904-1911 -except 1881, 1882, 1889 to 1892 are taken from the statistical yearbook Annuaire Statistique de la France as kept in the online website gallica.bnf.fr. The number for years 1890 to 1892 and 1900 to 1903 are taken from "Renseignements statistiques relatifs aux impots directs" that are kept in the Cujas library in Paris. 


\section{References}

Armantier, O., E. Ghysels, A. Sarkar, and J. Shrader (2015). Discount window stigma during the 2007-2008 financial crisis. Journal of Financial Economics 118(2), 317-335.

Bagehot, W. (1873). Lombard Street: a description of the money market (5th edition ed.). London: Henry S. King and Co.

Banerjee, A., E. Duflo, G. Postel-Vinay, and T. M. Watts (2010). Long run health impacts of income shocks: Wine and phylloxera in 19th century france. Rev. Econ. Stat. 92(4), $714-728$.

Baubeau, P. (2004). Les cathédrales de papiers: Naissance et subversion du systéme de l'escompte en France, XVIIIe-Premier XXe siècle. Ph. D. thesis, University of Paris West Nanterre.

Bazot, G. (2014). Local liquidity constraints: What place for central bank regional policy? the french experience during the belle epoque (1880-1913). Explorations in Economic History 52, 44-62.

Bignon, V., E. Caroli, and R. Galbiati (2016). Stealing to survive? crime and income shocks in 19th century france. Economic Journal forthcoming.

Bignon, V., M. Flandreau, and S. Ugolini (2012). Bagehot for beginners: The making of lender of last resort operations in the mid-19th century. Economic history review 65(2), 580-608.

Billoret, J.-L. (1969). Système bancaire et dynamique économique dans un pays à monnaie stable 1816-1914. Ph. D. thesis, University of Nancy.

Bindseil, U. and J. J. Jablecki (2013). Central bank liquidity provision, risk-taking and economic efficiency. Technical report, ECB working paper 203.

BIS (2013, March). Central bank collateral frameworks and practices. a report by a study group established by the markets committee. Markets committee publications no 6, Bank of International Settlements, Basel.

BIS-CGFS (2015, march). Central bank operating frameworks and practices. a report by a study group of the markets committee of the global financial system. CGFS papers 53, Bank of International Settlements, Basel.

Bouvier, J. (1973). Un siècle de banque Française. Paris: Hachette littérature.

Bouvier, J. (1979). Histoire économique et sociale de la France 1880-1950, Volume 1-2, Chapter L'extension des réseaux de circulation de la monnaie et de l'épargne, pp. 161198. Paris: PUF. 
Bravard-Veyrières, M. and C. Demangeat (1862). Traité de droit commercial, Volume III. Paris: Marescq Ainé, A.

Cameron, R. (1961). France and the economic development of Europe 1800-1914. Princeton: Princeton University Press.

Cameron, R. (1967). Banking in the early stage fo Industrialization. Oxford: Oxford University Press.

Chamley, C. and H. Polemarchakis (1984, January). Assets, general equilibrium and the neutrality of money. Review of Economic Studies 51(1), 129-138.

Chapman, J. and A. Martin (2013, June). Rediscounting under aggregate risk with moral hazard. Journal of Money, Credit and Banking 45(4), 651-674.

Contamin, R. and C. Denise (1999). Quelle autonomie pour les politiques monétaires sous l'étalon-or, 1880-1913? Économie internationale 78, p. 59-84.

Cúrdia, V. and M. Woodford (2011). The central bank balance sheet as an instrument of monetary policy. Journal of Monetary Economics 58(1), 54-79.

Dalloz, V. (1830). Traité des effets de commerce. Paris: Tarlier.

Dauphin-Meunier, A. (1936). La banqeu de France. Gallimard.

Delafortrie, N. and J. Morice (1959). Les revenus départementaux en 1864 et 1954. Paris: Librairie Armand Colin.

Domin, J.-P. (2007). La question du monopole d'émission de la monnaie: le débat banque banque centrale contre banque libre chez les économistes français. European Journal of Social Sciences XLV(137), 185-202.

Eichengreen, B. and M. Flandreau (1997). The Gold Standard in Theory and History (2nd ed.). London: Routledge.

Flandreau, M. (1996a). The French crime of 1873: An essay on the emergence of the International Gold Standard, 1870-1880. Journal of Economic History 56(4), 862-897.

Flandreau, M. (1996b). Les règles de la pratique. la banque de france, le marché des métaux précieux et la naissance de l'étalon-or, 1848-1876. Annales, Histoire, Sciences Sociales 51(4), 849-871.

Flannery, M. J. (1996). Financial crises, payment system problems, and discount window lending. Journal of Money, Credit and Banking 28(4), 804-824.

Freixas, X., J.-C. Rochet, and B. M. Parigi (2004). The lender of last resort: A twenty-first century approach. Journal of the european economic association 2(6), 1085-1115. 
Gale, G. (2011). Dying on the Vine. How Phylloxera Transformed Wine. Berkeley: University of California Press.

Galet, P. (1957). Cépages et vignobles de France. Montpellier: Imprimerie du Paysan du Midi.

Gertler, M. and N. Kiyotaki (2010). Handbook of Monetary Economics, Volume 3A, Chapter FInancial intermediation and credit policy in business cycle analysis, pp. 597-600. Amsterdam: Elsevier.

Gille, B. (1959). La banque et le crédit en France de 1815 à 1848. Paris: Presses Universitaires de France.

Gille, B. (1970). La Banque en France au 19ème siècle. Geneva: Droz.

Hoffman, P. T., G. Postel-Vinay, and J.-L. Rosenthal (2015). Entry, information, and financial development: A century of competition between french banks and notaries. Explorations in Economic History 55, 39-57.

Hoffman, P. T., G. Postel-Vinay, and L. Rosenthal (2001). Des marchés sans prix. Une économie politique du crédit à Paris, 1660-1870. Paris: Editions de l'EHESS.

Jobert, P. and J.-C. Chevailler (1986). La démographie des entreprises francaises en france au 19ème siécle. Economie et Société 2, 233-264.

Jobst, C. (2010). Gouverner une banque centrale: du XVIIe siècle à nos jours, Chapter Gouverner une banque centrale décentralisée: l'exemple austro-hongrois (1847-1914), pp. 113-142. Paris: Albin Michel.

Juglar, C. (1889). Des Crises Commerciales et de leur retour périodique en France, en Angleterre et aux États-Unis. Paris: Guillaumin.

Kaufmann, E. (1914). La Banque en France. M. Giard Editeurs.

Kiyotaki, N. and J. Moore (2005). Liquidity and asset prices. International Economic Review 46(2), 317-349.

Leclercq, Y. (2010). La Banque supérieure. La Banque de France de 1800 à 1914. Bibliothèque de l'économiste. Paris: Classiques Garnier.

Lescure, M. (2003). Politiques et pratiques des banques d'émission en Europe, XVIIe-XXe siécle, Chapter La formation d'un système de crédit en France et le rôle de la banque d'émission 1850-1914, pp. 131-148. Albin Michel.

Limousin, C. M. (1900). Philosophie de la statistique de faillite. Journal de la Société de Statistique de Paris 41, 52-61. 
Loua, T. (1877). Les faillites. Journal de la Société de statistique de Paris 18, 281-291.

Loubere, L. (1978). The Red and the White: A History of Wine in France and Italy in the 19th century. State University Of New York Press.

Millardet, A. (1877). La question des vignes américaines du point de vue théoqique et pratique. Bordeaux: Féret et fils.

Nishimura, S. (1995). The french provincial banks, the Banque de France, and bill finance, 1890-1913. Economic History Review 48, 536-554.

Percerou, J. (1935). Faillites, banqueroute et liquidations judiciaires. Paris: Rousseau.

Plessis, A. (1985). Régents et Gouverneurs de la Banque de France. Genève: Librairie Droz.

Plessis, A. (1991). Entre l'état et le marché. L'économie française des années 1880 à nos jours, Chapter Les banques, le crédit et l'économie, pp. 331-364. Paris: Gallimard.

Pose, A. (1942). La Monnaie et ses institutions, histoire, théorie et technique. Paris: Presses Universitaires de France.

Postel-Vinay, G. (1989). Agrarian Organization in the Century of Industrialization: Europe, Russia, and North America, Chapter Debts and Agricultural Performance in the Languedocian Vineyard, 1870-1914, pp. 161-186. Greenwich (CT): JAI Press.

Postel-Vinay, G. (1997). La Terre et l'argent. L'agriculture et le crédit en France du 18ème au début du 20ème siècle. Paris: Albin Michel.

Pouget, R. (1990). Histoire de la lutte contre le phylloxéra de la vigne en France. Paris: INRA.

Ramon, G. (1929). Histoire de la Banque de France d'après les sources originales. Paris: Grasset.

Roulleau, G. (1914). Des r'eglements par effets de commerce en France et a l'étranger. Paris: Imprimerie Dubreuil, Frérebeau et Cie.

Santarosa, V. A. (2015, September). Financing long-distance trade: The joint liability rule and bills of exchange in eighteenth-century france. Journal of Economic History 75(3), 690-719.

Tate, W. (1868). the modern cambist forming a manual of foreign exchanges in the different operations of bills of exchanges and bullion. London: Effingham Wilson Royal Exchange.

Thornton, H. (1802). An enquiry into the nature and effects of the paper credit of Great Britain. Knight and Compton. 
Venkateswaran, V. and R. Wright (2014). Pledgability and liquidity: A new monetarist model of financial and macroeconomic activity. NBER Macroeconomics Annual 28(1), $227-270$.

Wallace, N. (1981). A modigliani-miller theorem for open-market operations. American Economic Review 71(3), 267-274.

Williamson, S. D. (2014, October). Central bank purchases of private assets. Technical Report 2014-026, working paper of the Saint Louis Fed.

Wolfers, J. (2006). Did unilateral divorce laws raise divorce rates? a reconciliation and new results. American Economic Review 96(5), 1802-1820. 
B. Tables

Table 1: Summary statistics

\begin{tabular}{lccccc}
\hline \multicolumn{1}{c}{ Variable } & Mean & Std. Dev. & Min. & Max. & N \\
\hline Default rate & 0.234 & 0.175 & 0 & 3.585 & 6880 \\
Phylloxera spotted & 0.014 & 0.053 & 0 & 0.545 & 6880 \\
Phylloxera impactdummy & 0.012 & 0.048 & 0 & 0.545 & 6880 \\
Phylloxera impactvolume & 0.005 & 0.027 & 0 & 0.41 & 6880 \\
Number of BoF branches & 0.728 & 0.764 & 0 & 9 & 6880 \\
BoF branches per capita & 0.002 & 0.002 & 0 & 0.01 & 6880 \\
Deposit bank branches & 1.701 & 3.008 & 0 & 36 & 6880 \\
Deposit bank branches per capita & 0.004 & 0.007 & 0 & 0.05 & 6880 \\
Population density & 126.684 & 586.320 & 15.081 & 8932.035 & 6880 \\
Firm density & 0.043 & 0.014 & 0.007 & 0.081 & 6880 \\
Farmsize & 4.571 & 2.807 & 0 & 11.391 & 6880 \\
\hline
\end{tabular}


Table 2: Baseline estimations

\begin{tabular}{lcccc}
\hline \hline & $(1)$ & $(2)$ & $(3)$ & $(4)$ \\
& Baseline & Controls & Wine intensive & $\mathbf{1 8 6 3 - 1 8 9 0}$ \\
\hline Shock & $0.69^{* * *}$ & $1.21^{* * *}$ & $1.17^{* * *}$ & 0.72 \\
BdF branches & 0.23 & 0.40 & 0.42 & 0.45 \\
& -0.02 & -0.02 & -0.02 & 0.00 \\
BdF*shock & 0.01 & 0.01 & 0.01 & 0.01 \\
& $-0.46^{* * *}$ & $-0.75^{* *}$ & $-0.91^{* *}$ & $-0.72^{* *}$ \\
CL/SG & 0.11 & 0.35 & 0.36 & 0.29 \\
CL/SG*shock & & -0.00 & -0.00 & -0.00 \\
& & 0.00 & 0.00 & 0.00 \\
Population density & & $0.13^{*}$ & $0.15^{*}$ & 0.07 \\
& & 0.08 & 0.08 & 0.09 \\
Firms per capita & & $-0.00011^{* * *}$ & 0.00392 & -0.00004 \\
Farmsize*shock & & 0.00003 & 0.00352 & 0.00003 \\
& & $-3.23^{* *}$ & $-2.86^{*}$ & -5.01 \\
$R^{2}$ & & 1.36 & 1.61 & 3.23 \\
Observations & -0.082 & -0.056 & 0.035 \\
\hline \hline
\end{tabular}

All specifications include year and district fixed effects as well as district specific time trends. Residuals are clustered at the district le

${ }^{*} \mathrm{p}<0.1,{ }^{* *} \mathrm{p}<0.05,{ }^{* * *} \mathrm{p}<0.01$ 
Table 3: Estimations with alternative measure for eligibility

\begin{tabular}{|c|c|c|c|c|}
\hline & $(1)$ & $(2)$ & $(3)$ & $(4)$ \\
\hline & Baseline & Controls & Wine intensive & $1863-1890$ \\
\hline \multirow{2}{*}{ Shock $_{i t}$ : impactvolume ${ }_{i t}$} & $0.71^{* * *}$ & $1.00 * *$ & $0.94^{* *}$ & 0.50 \\
\hline & 0.26 & 0.41 & 0.43 & 0.50 \\
\hline \multirow[t]{2}{*}{ Elig $_{i t}:$ Branchcapit $i t$} & -2.20 & -1.94 & -4.34 & -0.00 \\
\hline & 3.60 & 3.48 & 4.75 & 2.62 \\
\hline \multirow{2}{*}{ Elig $_{i t} *$ Shock $_{i t}$} & $-199.35^{* * *}$ & $-209.80^{*}$ & $-255.38^{* *}$ & $-208.01^{*}$ \\
\hline & 61.44 & 118.51 & 123.86 & 114.05 \\
\hline \multirow[t]{2}{*}{ Deposit bank branches per capita } & & -0.78 & -0.21 & -0.85 \\
\hline & & 1.34 & 1.65 & 1.90 \\
\hline \multirow{2}{*}{ Deposit bank branches p.c. ${ }^{*} S h o c k_{i t}$} & & 35.29 & 40.26 & 10.96 \\
\hline & & 30.81 & 30.06 & 35.81 \\
\hline \multirow[t]{2}{*}{ Population density } & & $-0.00012^{* * *}$ & 0.00329 & -0.00005 \\
\hline & & 0.00003 & 0.00371 & 0.00003 \\
\hline \multirow[t]{2}{*}{ Firms per capita } & & $-3.10^{* *}$ & -2.71 & -5.08 \\
\hline & & 1.38 & 1.70 & 3.29 \\
\hline \multirow[t]{2}{*}{ Farmsize* Shock $_{i t}$} & & -0.076 & -0.055 & 0.050 \\
\hline & & 0.073 & 0.080 & 0.067 \\
\hline Fixed effects & yes & yes & yes & yes \\
\hline$R^{2}$ & 0.545 & 0.548 & 0.731 & 0.399 \\
\hline Observations & 6880 & 6880 & 3010 & 2080 \\
\hline
\end{tabular}

${ }^{*} \mathrm{p}<0.1,{ }^{* *} \mathrm{p}<0.05,{ }^{* * *} \mathrm{p}<0.01 ;$ Standard errors in parentheses

All specifications include year and district fixed effects as well as district specific time trends.

All variables are yearly, residuals are clustered at the district level. 
Table 4: Alternative estimations with crisis variable measured by phylloxera being spotted in the district

\begin{tabular}{|c|c|c|c|c|}
\hline & Baseline & Controls & Wine intensive & $1863-1890$ \\
\hline \multirow[t]{2}{*}{ Shock $_{i t}:$ Spotted $_{i t}$} & 0.19 & $0.43^{*}$ & $0.47^{*}$ & -0.03 \\
\hline & 0.12 & 0.23 & 0.24 & 0.18 \\
\hline \multirow[t]{2}{*}{ Elig $_{i t}:$ Branches\# ${ }_{i t}$} & $-0.02^{*}$ & -0.01 & -0.02 & 0.00 \\
\hline & 0.01 & 0.01 & 0.01 & 0.01 \\
\hline \multirow[t]{2}{*}{ Elig $_{i t} *$ shock $_{i t}$} & $-0.16^{* *}$ & $-0.38^{* *}$ & $-0.47^{* *}$ & $-0.33^{* * *}$ \\
\hline & 0.06 & 0.17 & 0.18 & 0.09 \\
\hline \multirow[t]{2}{*}{ Deposit bank branches \# } & & -0.00 & -0.00 & -0.00 \\
\hline & & 0.00 & 0.00 & 0.00 \\
\hline \multirow[t]{2}{*}{ Deposit bank branches* ${ }^{*} h o c k_{i t}$} & & 0.06 & $0.08^{* *}$ & $0.08^{*}$ \\
\hline & & 0.04 & 0.04 & 0.04 \\
\hline \multirow[t]{2}{*}{ Population density } & & $-0.00012^{* * *}$ & 0.00385 & -0.00005 \\
\hline & & 0.00003 & 0.00339 & 0.00003 \\
\hline \multirow[t]{2}{*}{ Firms per capita } & & $-3.36^{* *}$ & $-2.96^{*}$ & -5.01 \\
\hline & & 1.37 & 1.63 & 3.33 \\
\hline \multirow[t]{2}{*}{ Farmsize*shock } & & -0.016 & -0.016 & 0.033 \\
\hline & & 0.024 & 0.023 & 0.023 \\
\hline Fixed effects & yes & yes & yes & yes \\
\hline$R^{2}$ & 0.544 & 0.547 & 0.731 & 0.399 \\
\hline Observations & 6880 & 6880 & 3010 & 2080 \\
\hline
\end{tabular}

${ }^{*} \mathrm{p}<0.1,{ }^{* *} \mathrm{p}<0.05,{ }^{* * *} \mathrm{p}<0.01 ;$ Standard errors in parentheses

All specifications include year and district fixed effects as well as district specific time trends.

All variables are yearly, residuals are clustered at the district level. 
Table 5: Alternative estimation in which the crises are measured by variable impactdummy

\begin{tabular}{|c|c|c|c|c|}
\hline & Baseline & Controls & Wine intensive & $1863-1890$ \\
\hline \multirow[t]{2}{*}{ Shock $k_{i t}:$ impactdummy $y_{i t}$} & 0.11 & $0.34^{*}$ & $0.39^{*}$ & -0.11 \\
\hline & 0.09 & 0.21 & 0.23 & 0.17 \\
\hline \multirow[t]{2}{*}{ Elig $_{i t}:$ Branches\# $\#_{i t}$} & $-0.02 *$ & -0.02 & -0.02 & 0.00 \\
\hline & 0.01 & 0.01 & 0.01 & 0.01 \\
\hline \multirow[t]{2}{*}{ Elig $_{i t} *$ Shock $_{i t}$} & $-0.12^{* *}$ & $-0.27^{*}$ & $-0.38^{* *}$ & $-0.23^{* * *}$ \\
\hline & 0.06 & 0.15 & 0.16 & 0.06 \\
\hline \multirow{2}{*}{ Deposit bank branches \# } & & -0.00 & -0.01 & -0.00 \\
\hline & & 0.00 & 0.00 & 0.00 \\
\hline \multirow[t]{2}{*}{ Deposit bank branches $\#^{*} S h o c k_{i t}$} & & 0.04 & $0.06^{*}$ & 0.07 \\
\hline & & 0.03 & 0.03 & 0.05 \\
\hline \multirow[t]{2}{*}{ Population density } & & $-0.00011^{* * *}$ & 0.00395 & -0.00004 \\
\hline & & 0.00003 & 0.00339 & 0.00003 \\
\hline \multirow[t]{2}{*}{ Firms per capita } & & $-3.23^{* *}$ & -2.67 & -4.46 \\
\hline & & 1.40 & 1.65 & 3.38 \\
\hline \multirow[t]{2}{*}{ Farmsize $^{*} S h o c k_{i t}$} & & -0.018 & -0.017 & 0.030 \\
\hline & & 0.019 & 0.020 & 0.025 \\
\hline Fixed effects & yes & yes & yes & yes \\
\hline$R^{2}$ & 0.544 & 0.547 & 0.731 & 0.398 \\
\hline Observations & 6880 & 6880 & 3010 & 2080 \\
\hline
\end{tabular}

${ }^{*} \mathrm{p}<0.1,{ }^{* *} \mathrm{p}<0.05, * * * \mathrm{p}<0.01 ;$ Standard errors in parentheses

All specifications include year and district fixed effects as well as district specific time trends.

All variables are yearly, residuals are clustered at the district level. 
Table 6: Controlling for spatial autocorrelation of the error term

\begin{tabular}{|c|c|c|c|c|c|c|}
\hline & $\begin{array}{c}(1) \\
\text { Baseline }\end{array}$ & $\begin{array}{c}(2) \\
\text { Branch } \\
\text { density }\end{array}$ & $\begin{array}{c}(3) \\
\# \text { branch }\end{array}$ & $\begin{array}{c}(4) \\
\text { Spotted } \\
\text { \# branch }\end{array}$ & $\begin{array}{c}(5) \\
\text { Controls }\end{array}$ & $\begin{array}{c}(6) \\
\text { Controls }\end{array}$ \\
\hline \multirow[t]{2}{*}{ Shock $_{i t}:$ impactvolume $_{i t}$} & $0.68^{* * *}$ & $0.71^{* * *}$ & & & $1.21^{* * *}$ & $1.02^{* *}$ \\
\hline & 0.23 & 0.25 & & & 0.39 & 0.40 \\
\hline \multirow{2}{*}{ Shock $_{i t}$ : impactdummy $y_{i t}$} & & & 0.19 & & & \\
\hline & & & 0.12 & & & \\
\hline \multirow[t]{2}{*}{ Shock $_{i t}:$ Spotted $_{i t}$} & & & & 0.11 & & \\
\hline & & & & 0.09 & & \\
\hline \multirow[t]{2}{*}{ Elig $_{i t}:$ Branches\# $\#_{i t}$} & $-0.02^{*}$ & & $-0.02^{*}$ & $-0.02^{*}$ & $-0.02^{*}$ & \\
\hline & 0.01 & & 0.01 & 0.01 & 0.01 & \\
\hline \multirow[t]{2}{*}{ Elig $_{i t}:$ Branchcapit\# ${ }_{i t}$} & & -2.47 & & & & -2.21 \\
\hline & & 3.59 & & & & 3.46 \\
\hline \multirow[t]{2}{*}{ Elig $_{i t} *$ Shock $_{i t}$} & $-0.456^{* * *}$ & $-200.113^{* * *}$ & $-0.159^{* *}$ & $-0.121^{* *}$ & $-0.744^{* *}$ & $-211.187^{*}$ \\
\hline & 0.113 & 59.381 & 0.063 & 0.054 & 0.338 & 115.801 \\
\hline Deposit banks & & & & & -0.00 & \\
\hline branches & & & & & 0.00 & \\
\hline Branches deposit & & & & & & -0.718 \\
\hline banks per capita & & & & & & 1.332 \\
\hline \multirow[t]{2}{*}{ Deposit banks*Shock $k_{i t}$} & & & & & $0.13^{*}$ & 36.56 \\
\hline & & & & & 0.07 & 29.88 \\
\hline \multirow[t]{2}{*}{ Population density } & & & & & $-0.00011^{* * *}$ & $-0.00011^{* * *}$ \\
\hline & & & & & 0.00003 & 0.00003 \\
\hline Firms & & & & & $-3.299^{* *}$ & $-3.174^{* *}$ \\
\hline per capita & & & & & 1.35442 & 1.376 \\
\hline \multirow[t]{2}{*}{ Farmsize $^{*}$ Shock $_{i t}$} & & & & & -0.086 & -0.0804 \\
\hline & & & & & 0.061 & 0.072 \\
\hline Spatial & $6.644^{* *}$ & $6.817^{* *}$ & $6.878^{* *}$ & $6.946^{* *}$ & $6.987^{*}$ & $7.126^{*}$ \\
\hline lambda & 3.268 & 3.434 & 3.278 & 3.304 & 3.591 & 3.691 \\
\hline Variance & $0.0086^{* * *}$ & $0.0087^{* * *}$ & $0.0087^{* * *}$ & $0.0087^{* * *}$ & $0.0086^{* * *}$ & $0.0086^{* * *}$ \\
\hline sigma2_e & 0.003 & 0.0031 & 0.0031 & 0.0031 & 0.0031 & 0.003 \\
\hline$r^{2}$ & 0.021 & 0.020 & 0.021 & 0.021 & 0.100 & 0.105 \\
\hline Observations & 6880 & 6880 & 6880 & 6880 & 6880 & 6880 \\
\hline
\end{tabular}

${ }^{*} \mathrm{p}<0.1,{ }^{* *} \mathrm{p}<0.05,{ }^{* * *} \mathrm{p}<0.01$

All specifications include year and district fixed effects as well as district specific time trends;

All variables are yearly, residuals are clustered at the district level. 
Table 7: Endogeneity of BoF branching-1 year lag

\begin{tabular}{|c|c|c|c|c|c|c|}
\hline & $\begin{array}{c}(1) \\
\text { Default }\end{array}$ & $\begin{array}{c}(2) \\
\text { Default }\end{array}$ & $\begin{array}{c}(3) \\
\text { Shock }\end{array}$ & $\begin{array}{c}(4) \\
\text { Shock }\end{array}$ & $\begin{array}{c}(5) \\
\text { Default +shock }\end{array}$ & $\begin{array}{c}(6) \\
\text { Default +shock }\end{array}$ \\
\hline Default rate avg & 0.00 & $2.56 \mathrm{e}+61$ & & & 0.00 & $3.66 \mathrm{e}+61$ \\
\hline Phylloxera & & & 0.70 & 1.04 & 0.72 & 0.98 \\
\hline BoF present in district & & $0.00143^{* * *}$ & & $0.00142^{* * *}$ & & $0.00143^{* * *}$ \\
\hline Deposit bank city & & $4.82^{* * *}$ & & $5.17^{* * *}$ & & $4.81^{* * *}$ \\
\hline Capital city & & $4.99^{* * *}$ & & $4.92^{* * *}$ & & $4.98^{* * *}$ \\
\hline City pop & & 1.00 & & 1.00 & & 1.00 \\
\hline Pop rank $=1$ & & 1.00 & & 1.00 & & 1.00 \\
\hline Pop rank $=2$ & & $0.55^{*}$ & & $0.55^{*}$ & & $0.55^{*}$ \\
\hline Pop rank $=3$ & & $0.38^{* *}$ & & $0.39^{* *}$ & & $0.38^{* *}$ \\
\hline Pop rank $=4$ & & $0.09 * * *$ & & $0.09^{* * *}$ & & $0.09 * * *$ \\
\hline Pop rank $=5$ & & $0.06^{* * *}$ & & $0.06^{* * *}$ & & $0.06^{* * *}$ \\
\hline District pop & & $1.000001^{* * *}$ & & $1.000002^{* * *}$ & & $1.000001^{* * *}$ \\
\hline District surface & & $1.00017^{*}$ & & 1.00015 & & $1.00017^{*}$ \\
\hline No. of subjects & 1074 & 1054 & 1076 & 1059 & 1074 & 1054 \\
\hline No. of failures & 86 & 80 & 88 & 82 & 86 & 80 \\
\hline Time at risk & 50460 & 35088 & 50682 & 35268 & 50460 & 35088 \\
\hline Adj. R-Squared & 0.00 & 0.37 & 0.00 & 0.37 & 0.00 & 0.37 \\
\hline LR chi2 & 0.202 & 392.235 & 0.624 & 400.815 & 0.742 & 392.236 \\
\hline
\end{tabular}

Exponentiated coefficients. All variables lagged by 1 year.

${ }^{*} \mathrm{p}<0.1,{ }^{* *} \mathrm{p}<0.05, * * * \mathrm{p}<0.01$ 
Table 8: Endogeneity of BoF branching-2 year lagged

\begin{tabular}{|c|c|c|c|c|c|c|}
\hline & $\begin{array}{c}(1) \\
\text { Default }\end{array}$ & $\begin{array}{c}(2) \\
\text { Default }\end{array}$ & $\begin{array}{c}(3) \\
\text { Shock }\end{array}$ & $\begin{array}{c}(4) \\
\text { Shock }\end{array}$ & $\begin{array}{c}(5) \\
\text { Default + shock }\end{array}$ & $\begin{array}{c}(6) \\
\text { Default +shock }\end{array}$ \\
\hline Default rate avg & 0.00 & $2.56 \mathrm{e}+61$ & & & 0.00 & $1.17 \mathrm{e}+60$ \\
\hline Phylloxera & & & 0.82 & 1.26 & 0.84 & 1.18 \\
\hline BoF present in district & & $0.00^{* * *}$ & & $0.00^{* * *}$ & & $0.00^{* * *}$ \\
\hline Deposit bank city & & $4.82^{* * *}$ & & $5.29 * * *$ & & $4.93^{* * *}$ \\
\hline Capital city & & $4.9853^{* * *}$ & & $4.9191^{* * *}$ & & $4.9864^{* * *}$ \\
\hline City pop & & 1.00 & & 1.00 & & 1.00 \\
\hline pop rank 1 & & 1.00 & & 1.00 & & 1.00 \\
\hline pop rank 2 & & $0.55^{*}$ & & $0.55^{*}$ & & $0.56^{*}$ \\
\hline pop rank 3 & & $0.38^{* *}$ & & $0.38^{* *}$ & & $0.38^{* *}$ \\
\hline pop rank 4 & & $0.087080^{* * *}$ & & $0.087507^{* * *}$ & & $0.086875^{* * *}$ \\
\hline pop rank 5 & & $0.06^{* * *}$ & & $0.06^{* * *}$ & & $0.06^{* * *}$ \\
\hline District pop & & $1.00^{* * *}$ & & $1.00^{* * *}$ & & $1.00^{* * *}$ \\
\hline District surface & & $1.00^{*}$ & & 1.00 & & $1.00^{*}$ \\
\hline No. of subjects & 1074 & 1054 & 1076 & 1059 & 1074 & 1054 \\
\hline No. of failures & 86 & 80 & 88 & 82 & 86 & 80 \\
\hline Time at risk & 50460 & 35088 & 50682 & 35268 & 50460 & 35088 \\
\hline Adj. R-Squared & 0.00 & 0.37 & 0.00 & 0.37 & 0.00 & 0.37 \\
\hline LR chi2 & 0.202 & 392.235 & 0.188 & 400.997 & 0.341 & 392.328 \\
\hline
\end{tabular}

Exponentiated coefficients

${ }^{*} \mathrm{p}<0.1,{ }^{* *} \mathrm{p}<0.05,{ }^{* * *} \mathrm{p}<0.01$ 


\section{Documents de Travail}

600. M. Mogliani and T. Ferrière, "Rationality of announcements, business cycle asymmetry, and predictability of revisions. The case of French GDP” September 2016

601. R. S.J. Koijen; F. Koulischer; B. Nguyen and M. Yogo, "Quantitative Easing in the Euro Area: The Dynamics of Risk Exposures and the Impact on Asset Prices" September 2016

602. O. de Bandt and M. Chahad, “A DGSE Model to Assess the Post-Crisis Regulation of Universal Banks” September 2016

603. C. Malgouyres, "The Impact of Chinese Import Competition on the Local Structure of Employment and Wages: Evidence from France" September 2016

604. G. Cette, J. Lopez and J. Mairesse, "Labour market regulations and capital labour substitution” October 2016

605. C. Hémet and C. Malgouyres, "Diversity and Employment Prospects: Neighbors Matter!” October 2016

606. M. Ben Salem and B. Castelletti-Font, "Which combination of fiscal and external imbalances to determine the longrun dynamics of sovereign bond yields?" November 2016

607. M. Joëts, V. Mignon and T. Razafindrabe, "Does the volatility of commodity prices reflect macroeconomic uncertainty?" November 2016

608. M. Bussière, G. Gaulier and W. Steingress, "Global Trade Flows: Revisiting the Exchange Rate Elasticities" November 2016

609. V.Coudert and J. Idier, “An Early Warning System for Macro-prudential Policy in France” November 2016

610. S. Guilloux-Nefussi, “Globalization, Market Structure and Inflation Dynamics” December 2016

611. S.Fries, J-S. Mésonnier, S. Mouabbi, and J-P. Renne, "National natural rates of interest and the single monetary policy in the Euro Area" December 2016

612. J. Blaum, C. Lelarge and M. Peters, “The Gains from Input Trade with Heterogeneous Importers” December 2016

613. A. Penalver, “Optimal Monitoring of Long-Term Loan Contracts” December 2016

614. M. Isoré and U. Szczerbowicz, "Disaster Risk and Preference Shifts in a New Keynesian Model” December 2016

615. L. Chauvet and L. Jacolin, "Financial Inclusion, Bank Concentration and Firm Performance” December 2016

616. P. A. Pintus, Y. Wen, and X. Xing, "The Inverted Leading Indicator Property and Redistribution Effect of the Interest Rate" December 2016

617. G. Cette, R. Lecat \& C. Ly-Marin, "Long-term growth and productivity projections in advanced countries" December 2016

618. V. Bignon and C. jobst, "Economic Crises and the Eligibility for the Lender of Last Resort: Evidence from 19th century France" January 2017

Pour accéder à la liste complète des Documents de Travail publiés par la Banque de France veuillez consulter le site : www.banque-france.fr

For a complete list of Working Papers published by the Banque de France, please visit the website: www.banque-france.fr

Pour tous commentaires ou demandes sur les Documents de Travail, contacter la bibliothèque de la Direction Générale des Études et des Relations Internationales à l'adresse suivante :

For any comment or enquiries on the Working Papers, contact the library of the Directorate General Economics and International Relations at the following address :

BANQUE DE FRANCE

49- 1404 Labolog

75049 Paris Cedex 01

tél : 0033 (0)1 42977724 ou 0142926340 ou 4890 ou 6981

email : 1404-ut@banque-france.fr 